\title{
The Canadian Institute of Ukrainian Studies: Foundations
}

\author{
Volodymyr Kravchenko \\ University of Alberta
}

\begin{abstract}
The Canadian Institute of Ukrainian Studies (CIUS) became the second academic institution in the Western world to fully specialize in exploring Ukrainian history, culture, and current affairs after the Harvard Ukrainian Research Institute (HURI). Establishment of the CIUS in Edmonton was not predetermined. There were other ideas and competing projects with regard to place, profile, and institutional model of Ukrainian studies in Canada. Edmonton became a winner due to a unique combination of Western regionalism, multiculturalism, the makeup of the Ukrainian local community, and the personal qualities of that community's leaders. Contrary to widespread opinion, the CIUS did not copy the institutional model of the HURI. The CIUS model is unique, as it embraces a broad, interdisciplinary research agenda, and community-oriented activities related to education and culture.
\end{abstract}

Keywords: Canadian Institute of Ukrainian Studies, Edmonton, Winnipeg, Toronto, multiculturalism.

\section{INTRODUCTION}

Gor over forty years the Canadian Institute of Ukrainian Studies (CIUS) has been one of the only two academic institutes in the Western world fully specialized in exploring Ukrainian history, culture, and current affairs. Its purview has particularly embraced a broad variety of topics related to the Ukrainian community in Canada, as well as institutional and intellectual aspects of Ukrainian studies in the West since the 1960s. Although many insightful observations about CIUS activities can be found in the works of authors writing on the various aspects of the history of the institute (Berezkina; Klid and Yurkevich; Melnyk and Klid; Kohut; Nebesio), a comprehensive analysis of the institute's origins, activities, and accomplishments has yet to be made. ${ }^{1}$ When the institute approached its

\footnotetext{
${ }^{1}$ I express my gratitude to those who helped me with the editing of and comments regarding the draft of the manuscript, which went through several cycles of rewriting: Ksenia Maryniak, Myroslav Yurkevich, Frank Sysyn, Roman Senkus, and Svitlana Krys. Of course, the aforementioned are not responsible for the final version of the article.
} 
fortieth anniversary in 2016, I came up with a plan to mark this event with a conference and publishing project devoted to the history and current stateof-the-art of Ukrainian studies in Canada (Kravchenko, Ukrainian Studies in Canada: Texts and Contexts). ${ }^{2}$ Before, and especially during, the conference I started asking myself: What was the reason for establishing the CIUS after the establishment of the Ukrainian Research Institute (HURI) at Harvard University? Why was the CIUS organized in distant Edmonton rather than in one of the leading centres of Canadian political and cultural life? What was its initial conceptual and organizational model? In this article, I will try to answer at least some of these questions by summarizing and analyzing the main facts regarding the early history of the CIUS, which are scattered in various sources.

Among the latter, memoirs and reflections written by prominent scholars and public activists who were directly involved in the establishment and early development of the CIUS remain the most important sources of information (Decore; Khymka; Kohut; Lupul; Potichnyj; Savaryn; Slavutych; Sukhovers'ky). They are complemented with new archival findings from the University of Alberta and CIUS archives as well as personal correspondence and periodic and secondary sources. My intention was to approach the issue from a broad perspective of the history of Ukrainian studies in Canada after World War II, with an emphasis on their intellectual and institutional aspects. The history of the CIUS is a result of many alternatives and mutual compromises rather than a saga of heroic deeds and many accomplishments. This article is a continuation of my previously published articles on similar topics ("Lystuvannia Romana Shporliuka," "Ukrainian Historical Writing," and Ukrainian Studies in Canada: Texts and Contexts).

\section{FRAMING A CONTEXT}

In Canada, in the words of Margaret Conrad, "the directions [of the academic study of history] were inspired by developments in Europe and the United States, but the applications were distinctly Canadian" (43). The same can be said about Ukrainian studies in Canada. They benefitted enormously from the several waves of immigration that brought with them professional cadres, institutions, and knowledge, first from Europe and later from the

\footnotetext{
${ }^{2}$ Scholarly articles on this topic have been published in a special thematic section of "Ukrainian Studies in Canada since the 1950s" in the East/West: Journal of Ukrainian Studies, vol. 5, no. 1, 2018, pp. 3-137, guest edited by Roman Senkus. Paul Robert Magocsi's valuable reflections, designed to open a new publishing series under the title of "CIUS Occasional Papers," for some reasons were issued independently (Magocsi, On Becoming a Ukrainianist).
} 
USA. These European, Canadian-American, and global Ukrainian diaspora (or pan-Ukrainian ${ }^{3}$ ) contexts formed a broad transnational framework for the development of Ukrainian studies in Canada. However, within this framework they have gradually acquired a specific profile through dialogues with the political and academic mainstream in Canada on the one hand, and with the Ukrainian-Canadian community on the other.

The consensus is that the Ukrainian community in Canada became as diverse as Ukrainian society in the "old country" (Ukrainian Studies in Canada: Texts and Context 46). ${ }^{4}$ As assessed by Vic Satzewich, "it is difficult to speak of a single diaspora and its goals precisely because of the heterogeneous nature of any group of individuals. In a sense, there is not a single diaspora, there are many diasporas" (218). Among many others, the dividing lines created in the Ukrainian-Canadian community along religious, regional, ideological, and political cleavages, the division between pre- and post-World War II Ukrainian immigrants deserves special attention (Luciuk 214-23). As John Gregorovich once put it, "these two different groups of Ukrainians-however similar they may have appeared-were really very different" (Luciuk and Hryniuk 80).

Essentially, the former prioritized Canada over Ukraine, and were concerned about the preservation of their cultural heritage and identity, mostly in order to be "good Canadians." The latter considered Ukraine not only as their only homeland but also as the focus of their various activities. They saw themselves as part of the global Ukrainian diaspora, no matter what country they resided in. Paul Robert Magocsi labels the former "Canadians of Ukrainian background" and the latter "Ukrainians who live in Canada" (Preface xii). In this article, I use terms such as Ukrainian Canadians and postwar Ukrainian émigrés to describe each group, respectively.

Previous scholars have shown numerous differences between these two groups of Ukrainian immigrants in Canada based on the issues of collective identity, memory, social values, political culture-and, it must be said, mutually negative stereotypes (see, for example, Satzewich 87, 102; Luciuk and Hryniuk 60-61, 66, 80). These scholars have also held differing views on the institutional history of the Ukrainian community in Canada. Ukrainian

\footnotetext{
3 This term includes Ukraine itself after the country gained independence with the collapse of the Soviet Union in 1991.

${ }^{4}$ Ukrainian Studies in Canada: Texts and Contexts, edited by me, Multiculturalism and Ukrainian Canadians: Identity, Homeland Ties, and the Community's Future, edited by Lubomyr Luciuk and Stella Hryniuk, and Ukraine in the Seventies: Papers and Proceedings of the McMaster Conference on the Contemporary Ukraine, Hamilton, Ont., 1974, edited by Peter J. Potichnyj, are transcriptions of papers, rather than collections of articles. Therefore, when quoting from these publications, I will reference the entire book as opposed to individual articles.
} 
Canadians insist, as Frances Swyripa argues, that the basis of their organized community life in western Canada came into being before World War II (Luciuk and Hryniuk 61). The new immigrants, in turn, consider the institutions they brought with them to be a continuation of the Ukrainian academic and scholarly traditions established by the Shevchenko Scientific Society (1873) and the All-Ukrainian Academy of Sciences (1918). In the first case, institutions like the Petro Mohyla Institute in Saskatoon or the Hrushevsky Institute, later named St. John's Institute, in Edmonton were in fact modelled on the bursy created in Galicia before World War I and are based on educational, and cultural priorities (see Pered Bramoiu; Ukrains'kyi instytut im. P. Mohyly; and Sorokolittia Instytutu Sv. Ivana). Meanwhile, postwar immigrants' organizations such as the Ukrainian Free Academy of Sciences (UVAN, see Rozumnyj, "UVAN in Canada") and the Shevchenko Scientific Society of Canada (NTSh-K) (Darevych) were recognized academic institutions that crossed the ocean with them into the New World.

The latter two organizations were the most important among postwar Ukrainian immigrants' scholarly bodies. They contributed to a new geographical dimension of Ukrainian studies in Canada. The UVAN was established in Winnipeg, the de facto cultural capital city for Ukrainian Canadians (see Pinczuk; Kravchuk). The academy became "Canadianized" in terms of its research priorities and publishing activities. The NTSh found its place in Toronto, the main political and intellectual base of postwar Ukrainian émigrés (see Gregorovich, Ukrainian Toronto). Ironically, the new cultural geography of the Ukrainian community in Canada coincided with Canada's regional division between the predominantly agricultural west and the more industrial east.

Thus, while representatives of both these groups in Canada have engaged in Ukrainian studies in a broad sense, they have had different ideas about the content and meaning of the field. Ukrainian Canadians have traditionally prioritized disciplines directly connected to their ethnicity and to the preservation of their cultural heritage, like language, folklore, church, museum, and family studies. The postwar émigrés primarily dealt with disciplines and topics related to the Ukrainian national grand narrative; in parallel with the traditional humanities, they have emphasized (geo)political studies, economics, and other areas. Hence, Ukrainian-Canadian topics are usually placed in the disciplinary framework of Canadian studies, while panUkrainian topics have been primarily encompassed by East European, Slavic, and Soviet studies.

The above-described differences between Ukrainian Canadians and Ukrainian postwar émigrés should not obscure the fact that these two groups needed and complemented each other. Ukraine-oriented activities and topics helped the Ukrainian Canadians to legitimize their distinctiveness, especially during the era of multiculturalism in the 1960s- 
70s. In turn, Canada-oriented topics helped the émigrés to acculturate to the new country. Both Ukrainian-Canadian studies and pan-Ukrainian studies have overlapped, but each has retained specific features in terms of topics, priorities, and disciplinary identity.

\section{THE AMERICAN CHALLENGE}

After World War II, in many ways Canadian university education and scholarship followed the US's lead. During American cultural expansion in the early 1960s, Canadian universities "not only imitated the American model, but had recruited Americans to fill thousands of vacancies" (Anderson, "The Elephant" 6). Universities and colleges in the United States created standards that were followed in Canadian higher education, and were included in the new areas of East European, Slavic, and Soviet studies. Many postwar immigrants, as well as Canadian citizens, studied in the United States before occupying teaching positions at Canadian universities. Among them, we see leading specialists in various disciplines who established the present scholarly field of Ukrainian studies in Canada. ${ }^{5}$ The number of U.S. university graduates in Canada grew steadily owing to favourable conditions in the Canadian academic job market (see Potichnyj, My Journey 181-83).

In the 1960s, institutional and intellectual revisions of Ukrainian studies came north from a new generation of Ukrainians whose outlook was shaped by their education in the United States, rather than by their émigré experience. This generational shift, sometimes perceived as a conflict, coincided with paradigm shifts in the humanities and social sciences as well as with a growing awareness of the difficulties experienced by ethnic minorities in gaining academic and social legitimacy (Rojas). The permanent tensions between various émigré factions hindered an update of academic agendas and institutional development of Ukrainian studies (Atamanenko $102,112,133)$.

The most ambitious alternative to the traditional immigrant-based concept of Ukrainian studies was elaborated by Omeljan Pritsak (19192006), an Orientalist and historian who emigrated from West Germany to the United States in 1961 to become a professor at Harvard University (Keenan). In 1972, Pritsak expressed strong criticism of Ukrainian émigré scholars, accusing them of intellectual conservatism, lack of scope, and

\footnotetext{
${ }^{5}$ Among them were Slavists (Constantine Andrusyshen, Metro Gulutsan, Celestin [Mykola] Suchowersky, Yar Slavutych, Oleh Zujewskyj, and Victor Buyniak); political scientists (Bohdan R. Bociurkiw and Peter J. Potichnyj); a philologist (George S. N. Luckyj); historians (Ivan L. Rudnytsky and Paul Yuzyk); a sociologist (Wsevolod W. Isajiw); and a specialist in the history of education (Manoly R. Lupul).
} 
dilettantism, and called for radical institutional and methodological changes ("The Present State of Ukrainian Studies" 147-50). He called for the liberation of Ukrainian studies from the "émigré ghetto," integration into the western academic milieu, and an intellectual revision and "secularization" of Ukrainian studies. The message was clear: Ukrainian studies were in a need of a new concept, a new institution, and a new generation of scholars to be able to meet world-recognized standards of research and teaching (Pritsak, Chomu katedry ukrainoznavstva 3, 15-25, 67).

Pritsak put forward an initiative to establish a Ukrainian research institute at Harvard University-actually, a research and teaching centre or hub with three endowed chairs (in Ukrainian language, literature, and history) and its own publishing house and specialized library (Pritsak, Chomu katedry ukrainoznavstva). He started an aggressive fundraising campaign within the Ukrainian-American community that resulted in the creation of a financial basis for the three endowed chairs at Harvard. These three chairs, in turn, became the basis for the Harvard Ukrainian Research Institute (HURI) officially established in 1973. The main task of such a centre would be to train a new generation of Ukrainianists and raise the academic profile of Ukrainian studies in the world.

Pritsak saw the new institute as a continuation of the Ukrainian academic tradition that Volodymyr Antonovych established in Kyiv (see Antonovych, 125 rokiv) and that was advanced by the Lviv school of Ukrainian studies headed by Ivan Kryp"iakevych. In fact, the HURI became a truly visionary project that broke down the self-isolationism of the political Ukrainian émigré institutions in the name of "purity" of Ukrainian academic scholarship. In 1973, Pritsak became the founding director of the HURI, which was to develop into a prominent centre of Ukrainian studies in the Western world, an incubator for new generations of specialists in North America.

Pritsak provoked a veritable uproar in the Ukrainian community, both in the United States and in Canada (Atamanenko 270-79, 302, 304, 521-26; Satzewich 127). Some Ukrainian scholars expressed concerns that the HURI would be susceptible to "Russification," and proposed to put it under the strict control of the Ukrainian community (Shtohryn). Others felt offended by Pritsak's harsh diagnosis of the émigré scholars and institutions (Dombrowskyi). Pritsak's followers on both sides of the American-Canadian border, however, met his project with enthusiasm and supported it politically and financially. Pritsak insisted that Ukrainians "must unite and work together, disregarding national boundaries, since the problem of establishing a basis for Ukrainian identity is equally relevant to the Ukrainians in the United States and to those in Canada" (Chomu katedry ukrainoznavstva 169). Pritsak actively promoted the HURI project during his 
lecture tour across Canada in 1971, when he met with local community activists in Winnipeg and Edmonton.

Professor Manoly R. Lupul of the University of Alberta assessed the HURI project as having "wide appeal especially to the postwar Ukrainian immigrants in eastern Canada, many of whom were . . . contributing generously to the establishment of three chairs . . . and a research institute at Harvard" ("The Establishment of the Canadian Institute" 15-16). A Canadian committee in support of the HURI was even established in Toronto, under the leadership of Peter (Petro) Jacyk, a postwar Ukrainian immigrant and successful entrepreneur (Slaboshpyts'kyi and Soroka). Many prominent Ukrainian activists and intellectuals, including Peter Savaryn, Paul Yuzyk, and Wasyl Veryha, became members of the committee. They managed to raise almost thirty-five thousand dollars in support of the HURI, of which Jacyk himself donated the main portion. The HURI could have become a joint American-Canadian enterprise, dominated by American-based scholars. But Ukrainian studies in Canada acquired a different direction and application, at both institutional and intellectual levels.

\section{The CANADIAN CONTEXT}

After World War II, Canada entered a period of intensive nation-state building. New ideological trends-nationalism, anti-colonialism, and socialism-affected the political and intellectual climate in the country (Cormier 357; Palmer 6-22). The Canadian nation-in-the-making often emphasized its distinctiveness from the United States: "We are not Americans" was the standard refrain (Patrick and Kasoff 382-83). Education became perhaps the main battlefield for Canadian identity. During the late 1960s and early 1970s, a movement emerged that aimed to "nationalize" Canadian universities and protect them from "American colonization." The "Canadianization" advocates desired more Canadian faculties, students, studies, research materials, and textbooks to address local realities (Cormier).

Students became a vital part of the movement:

They supported professors making change and suggested areas for addition and expansion. Not only did they contribute through their newspapers and radio stations, but also they were-imaginatively and independentlycreators, organizers, and administrators of guest lectures, debates, and large teach-ins which affected both university and public attitudes. (Steel and Mathews 505)

It would be fair to assume that the "Canadianization" movement, along with its anti-colonial and socialist overtones, resonated well with second- 
generation Ukrainian youth who were interested in Ukrainian studies, especially members of the Ukrainian Canadian Students' Union (SUSK) under the leadership of Bohdan Krawchenko, later (in 1986-90) the director of the CIUS (Ukrainian Studies in Canada: Texts and Contexts 23). Garth Stevenson convincingly concluded that the first steps toward the Canadian policy of multiculturalism were made by John Diefenbaker at the end of the 1950s, the first prime minister to have grown up in Saskatchewan (209-14). The later political crisis in Quebec on exacerbated questions of Canadian cultural identity, in turn brought up the issue of the "third force," i.e., the role of numerous immigrant ethnic communities in the Canadian nation-state (Lalande; Champion).

The Royal Commission on Bilingualism and Biculturalism (B\&B Commission) was established in 1963 to investigate the relationship between Canadian anglophones and francophones. ${ }^{6}$ In 1969 the B\&B Commission produced a recommendation to acknowledge the cultural contribution of other ethnic groups to Canadian life (see Report of the Royal Commission on Bilingualism and Biculturalism). This "gave the ethnic communities additional stimulus and encouragement to continue, more rigorously and with greater enthusiasm, in their efforts for their own linguistic and cultural preservation" (Buyniak 80). The new Canadian policy of multiculturalism was born and officially implemented in 1971.

In "The Establishment of the Canadian Institute of Ukrainian Studies," Lupul later referred to the B\&B Commission's report "as the 'Magna Carta' of Canada's ethnocultural minorities" (4). As one of the largest ethnic communities in Canada, Canada's Ukrainians actively participated in the development and implementation of the multiculturalism policy (Lalande; Kordan; Rozumnyj). In turn, the multiculturalism policy can be said to have essentially legitimized the Ukrainian community as a respectable participant in Canadian political and cultural life. Moreover, it separately affected both Ukrainian Canadians and postwar Ukrainian immigrants and created new possibilities for their fruitful co-operation (Sukhovers'kyi 216).

One of the founding fathers of this policy was a Canadian-born history professor from Winnipeg, Senator Paul Yuzyk (Karpyak; Duravetz). At the Ukrainian Canadian Committee's request, a recent Ukrainian immigrant, Professor Jaroslav B. Rudnyckyj, was appointed by Prime Minister Lester B. Pearson to the B\&B Commission, and he authored the Ukrainian-related parts of its final report (Kondra 39). The Report of the Royal Commission on

6 As André Laurendeau put it, "The Royal Commission on Bilingualism and Biculturalism was arguably the most important-also the most lengthy, the most expensive and the most controversial-commission of inquiry in Canadian history" (Laurendeau and Smart 3). 
Bilingualism and Biculturalism gave a strong impulse to new Ukrainianrelated projects and programs.

The policy of multiculturalism was perceived and interpreted differently by its proponents and opponents (Stevenson 206). The Ukrainian community's needs and aspirations were not clearly articulated, and the community largely imitated the French-Canadian example by formulating multicultural action programs (Rudnyts'kyi 122-24; Sukhovers'kyi 215-16). Usually, these programs included measures to develop Ukrainian-language education, maintain and explore Ukrainian cultural heritage, and represent Ukrainian contributions to Canadian society. Differences emerged in articulating ideas about priorities, common actions, mechanisms, and political leadership. It would be fair to say that Canada's Ukrainians were better consolidated, organized, and therefore more effective, at the regional rather than the national level.

The Canadian nation-state building project also acquired a visible geographical dimension in the search for possible formulas to define relations between the provinces and the federal government. Hence the issue of political regionalism became no less important than the issues of "Canadianization" and multiculturalism (Alcantara et al.; Cochrane and Perrella; Friesen). The "ethnics" and the "regionalists" became close political allies, especially in the provinces with compact ethnic minorities, such as those in the Canadian Prairies, which were heavily impacted by the first two waves of Ukrainian immigration. Canadians of Ukrainian origin were especially well represented in the political and business establishments of Alberta, Manitoba, and Saskatchewan. Many of them were sensitive to the cultural needs of local Ukrainian communities, whose strong Ukrainian presence contributed to the development of both national and regional identities in Canada.

The HURI and Canadian multiculturalism could not but influence further development of Ukrainian studies in Canada. Starting in the early 1970s, different groups of scholars and community activists expressed ideas for establishing centres for Ukrainian studies in different Canadian cities, such as Winnipeg, Toronto, Ottawa, Edmonton, and Saskatchewan (Lupul, The Politics of Multiculturalism 240-41; Savaryn, "Kanads'ka fundatsiia ukrains'kykh studii" 50). Earlier, Pritsak had identified two possible ways to establish a Ukrainian studies centre or research institute (Chomu katedry ukrainoznavstva 169-70). According to Pritsak, such a centre could be established either at a separate Ukrainian university or at the best American (or in this case Canadian) university. Pritsak considered the idea of a Ukrainian university in the United States to be highly desirable but unrealistic, owing to the Ukrainian diaspora's scarce financial resources. However, Canada was better positioned for such a possibility. 


\section{WINNIPEG}

The fourth volume of the B\&B Commission's final report specifically recommended that Canadian universities "expand their studies in the fields of the humanities and the social sciences relating to particular areas other than those related to the English and French languages" (Report of the Royal Commission on Bilingualism and Biculturalism 167). Although the commission did not recommend establishing separate Ukrainian or German ethnic universities in the western provinces, it did not deny such a possibility at the federal level. ${ }^{7}$ This passage, written undoubtedly by Jaroslav B. Rudnyckyj, the only Ukrainian member of the B\&B Commission, obviously implied that the University of Manitoba, his host institution, was the best place for such an endeavour. Indeed, he had many reasons for such a recommendation.

Rudnyckyj maintained a close relationship with his alma mater, the Ukrainian Free University in Munich, and was directly involved in its academic and teaching activities, which partly explains his inclination toward a university model of Ukrainian studies (Szafowal and Yaremko 21521). The Ukrainian Orthodox St. Andrew's College in Winnipeg, chaired by Metropolitan Ilarion (Ohiienko, aka Ohienko), already offered several university-level courses for Canadian students and was in the process of affiliating with the University of Manitoba. In addition, Winnipeg hosted several other Ukrainian community research, cultural, and publishing institutions, like the Ukrainian Free Academy of Sciences (UVAN), the Ukrainian Cultural and Educational Centre (Oseredok in Ukrainian), and the Research Institute of Volyn, with its own press house and periodical. All of the above-mentioned institutions created an academic-friendly environment for Ukrainian studies in Winnipeg.

Winnipeg already had a positive experience of fruitful co-operation between the earlier Ukrainian Canadians and the postwar Ukrainian immigrants. Rudnyckyj, who was the founding chair of the Department of

\footnotetext{
7 The following fragment of the report is worth quoting in its entirety: "We note the formation of colleges serving particular cultural groups and employing the languages of those groups in addition to English, French, or both the official languages. For example, in Manitoba, a Ukrainian Orthodox college (St. Andrew's) is part of the University of Manitoba; a Ukrainian Catholic college (St. Vladimir's) intends to become a degree-granting institution; and a research institute (the Ukrainian Free Academy of Sciences) has an adult education program in Ukrainian studies. Such institutions could form a federated university and they should be free to do so. Probably, for both academic and financial reasons, they would prefer to be part of one of the larger, existing universities" (Report of the Royal Commission on Bilingualism and Biculturalism 167-68).
} 
Slavic Studies at the University of Manitoba and served as president of the UVAN in Canada for about fifteen years, made a great contribution to the "Canadianization" of Ukrainian studies in Winnipeg (Prymak 53-76). Mykhailo (Michael) Marunchak, a postwar immigrant and an UVAN member, wrote a number of books on the history of Ukrainians in Canada. Rudnyckyj's colleagues - the historians Paul Yuzyk and Alexander Baran and the philologist Jaroslav Rozumnyj-also contributed to the development of Ukrainian studies at the University of Manitoba, demonstrating that the university was open to the idea of establishing of a Ukrainian studies centre.

Winnipeg's solid reputation in Ukrainian and Slavic studies was complemented by its political potential; since 1940 the national executive of the Ukrainian Canadian Committee (UCC, now Congress) has been located in Winnipeg. The Manitoba Mosaic Congress held in Winnipeg in October 1970 obtained local political support for the ethnic communities' cultural demands. A long-time mayor of the city, Stephen Juba (Ukr: Stepan Dziuba), was personally involved in many Ukrainian cultural initiatives. It was no coincidence that after announcing the official Canadian multiculturalism policy to the House of Commons in Ottawa, Prime Minister Trudeau addressed the UCC convention in Winnipeg on October 9, 1971.

Winnipeg's drawbacks were of a subjective nature. After Rudnyckyj ceased to be president of the UVAN in 1969, the latter became mired in a deep crisis that lasted for about five years (Rozumnyj 124). In 1976, Rudnyckyj officially resigned as chair of the Department of Slavic Studies. His departure from the University of Manitoba substantially reduced the chances of Winnipeg becoming the Ukrainian university centre (Lupul, "The Establishment of the Canadian Institute of Ukrainian Studies"). In addition, a distinct Orthodox profile as well as the close association of St. Andrew's College and the UVAN with émigré institutions and scholars had little appeal for non-Orthodox Ukrainian-Canadian stakeholders. Thus, while it was actively supported and promoted by the UCC and some leaders in the Ukrainian Canadian Professional and Business (P\&B) Club, the idea of a Ukrainian university and/or research institute in Winnipeg yielded to other competing projects (Lupul, The Politics of Multiculturalism 240-42).

\section{TORONTO}

As the main political, cultural, and economic hub of Ukrainians in Canada, and the unofficial capital of new immigrants, Toronto had the best chance to become a worthy rival of Winnipeg as the site for a new institute of Ukrainian studies (Wynnyckyj; Gregorovich). The University of Toronto was considered one of the world's best universities. The renowned scholar George S. N. Luckyj, a leading Ukrainian professor at the University of 
Toronto, elaborated a research and publishing project aimed at supplying students with English-language basic texts in different disciplines of Ukrainian studies (Potichnyj, Ukraine in the Seventies 350). A Ukrainian research centre at the University of Toronto was a future objective of the program ("Z zhyttia ukraintsiv" 120-21). The local Ukrainian community's well-developed network of educational and cultural institutions and financial and political potential created conditions for the implementation of such plans.

Peter Savaryn observed, "our well-to-do people in the East, who belong to the 'new' immigration, show more understanding for Ukrainian cultural needs than their counterparts in the West" (Lupul, The Politics of Multiculturalism 247). The idea of establishing a Canadian analogue of the "Ukrainian Harvard" at the University of Toronto appealed to many Ukrainian activists and scholars (Lupul, The Politics of Multiculturalism 24849). Manoly R. Lupul, Peter Savaryn, Stanley Frolick, Ivan L. Rudnytsky, and even Volodymyr Kubijovyč - the "last of the Mohicans" scholar and organizer of Ukrainian studies in Western Europe-were all in favour of Toronto (Savaryn, "Spohady uchasnyka" 357). Ukrainian activists and organizations started a fundraising campaign and began negotiations with the provincial government with the purpose of establishing a chair, if not an institute, of Ukrainian studies at the University of Toronto.

However, the ambitious idea of a "Canadian Ukrainian Harvard" in Toronto shared the fate of the idea of a Ukrainian university in Winnipeg. The University of Toronto had less Ukrainian courses than its counterparts in Ottawa, Alberta, and Winnipeg. (Report of the Royal Commission on Bilingualism and Biculturalism 164). Also, the University of Toronto was not as open as Harvard to Ukrainian institutional projects. It promised no more than a "Ukrainian Ethnic Research Centre" as part of the university's centre for Russian and East European Studies (Lupul, "The Establishment of the Canadian Institute of Ukrainian Studies" 17). The Ontario government, in turn, was ready to provide only modest financial support, limited to the establishment of a professorship with a secretary. In addition, the first fundraising campaigns in support of Ukrainian studies in Toronto did not elicit much enthusiasm in the local Ukrainian community. As Lupul remarks, "the thought of trying to raise two million dollars a la Harvard . . . is positively mind-boggling in the present 'uneducated' state of the Ukrainian community in Canada" ("The Establishment of the Canadian Institute of Ukrainian Studies" 8).

Finally, it should be admitted that Luckyj, who had a brilliant reputation in the academic world, treat Ukrainian immigrant communities in Canada with ill-concealed contempt (Luts'kyj, "Kanada-za i proty"). No wonder that, according to Lupul, "Luckyj disliked Ukrainian-Canadian politics and preferred to keep community leaders at arm's length" (The Politics of 
Multiculturalism 258). Luckyj's vision of the development of Ukrainian studies in Canada had a somewhat limited character:

We are not aiming at what Harvard and other places are trying to achieve. Our objective is much more modest.... In the next five years, we plan to publish 20 such textbooks in Ukrainian language, literature, history and political science .... They will have to be in Ukrainian and in English, and some of them even bilingual. (Potichnyj, Ukraine in the Seventies 350-53)

Obviously, these plans were timely and important for the development of university-based teaching programs, but they lacked the attractiveness of a grand idea like the one that inspired the promoters and supporters of the Harvard project. Both Winnipeg and Toronto, the two main centres of Ukrainian cultural, educational, and scholarly life in Canada, lacked a leadership able to respond to new challenges and take advantage of new opportunities for the development of Ukrainian studies.

\section{OTTAWA}

As hopes dimmed for the establishment of an institute of Ukrainian studies at the University of Toronto, Ottawa, as the nation's capital, seemed to be the logical next choice. In the mid-1960s, the University of Ottawa had the largest number of Ukrainian courses in literature and language of all Canadian universities (Report of the Royal Commission on Bilingualism and Biculturalism 164). Ukrainian-Canadian studies at the University of Ottawa were initiated by Vladimir J. (Kaye) Kysilewsky, the first president of the Canadian Association of Slavists (Martynowych; Bociurkiw), and were successfully continued by the University of Ottawa Slavist Constantine Bida, the historian Ivan Teslia, the political scientist Theofil Kis, and the historian and senator Paul Yuzyk. Professor Bohdan R. Bociurkiw, a well-known political scientist and historian of modern Ukraine, had been at Carleton University since 1969 and had become the founding director of the Institute of Soviet and East European Studies there.

Although the University of Ottawa was not considered to be in the same league as the University of Toronto, it could compensate for its academic drawbacks with political capital. Proximity to the federal government opened up opportunities for attracting funds and raising the project's political profile. Senator Yuzyk, the well-connected politician and one of the "fathers" of Canadian multiculturalism, actively lobbied to make the University of Ottawa the site of a future institute or centre of Ukrainian studies. The first financial contribution to support the idea of the development of Ukrainian studies in Ottawa was made in 1973 by Nadia and 
Antin Iwachniuk of Toronto, who established the Iwachniuk Fund at the University of Ottawa to encourage research in and publication of Ukrainian studies. This fund laid the groundwork for the endowed Chair of Ukrainian Studies that was formally established at the University of Ottawa in 1993.

At the same time, the Ottawa project had many disadvantages. Professor Bida, the head of the Department of Slavic Studies at the University of Ottawa, did not have the same reputation as Luckyj or Jaroslav B. Rudnyckyj. His reflections on the state of and prospects for the development of Ukrainian studies in Canada looked modest and abstract (Potichnyj, Ukraine in the Seventies 353-55). Meanwhile, Senator Yuzyk could not fully devote himself to scholarly work because of his political responsibilities. In addition, the University of Ottawa did not clearly express its position on creating a Ukrainian institute or research centre. Some Ukrainian activists thought a Ukrainian institute might be susceptible to Franco-Canadian and Catholic political influence (Lupul, The Politics of Multiculturalism 241).

It would be fair to conclude that Winnipeg, in spite of its many drawbacks and shortcomings, was in the best position to become the site of a national institute of Ukrainian studies. Its demographic and intellectual resources, its institutional network, and its political support from the local Ukrainian community, made the city a true leader in comparison with other Ukrainian centres in Canada. All of the other potential candidates for hosting a future institute-including Toronto and Ottawa-had to deal with many more obstacles if they were to be contenders for the title of "Ukrainian studies capital of Canada." But none of the candidates was ready to present a clearly articulated concept of such an institute. In what follows I focus on Edmonton, and trace how the idea of the Canadian Institute of Ukrainian Studies was born, developed, and finally implemented in this city.

\section{EDMONTON}

Edmonton's chance to establish an institute of Ukrainian studies looked problematic compared to the three cities mentioned above. But in the 1970s, Edmonton was a dynamic city, whose importance in Ukrainian and Canadian life was growing fast for economic and political reasons. Several factors contributed to this process. First, with the rise of the Progressive Conservative government in 1971, Alberta entered a period of impressive political and financial growth (Elton and Goddard; Alcantara et al.; Bell). Second, both Canadian-born Ukrainians and postwar Ukrainian émigrés actively participated in this process. Edmonton's Ukrainians managed to avoid a lengthy conflict between different émigré factions to establish "a fruitful co-operation among themselves" (Khymka 99). Starting in the late 1950s, local community activists repeatedly requested that Ukrainian 
language classes be offered in all grades in high schools and at the University of Alberta (Ukrainians in Alberta 205). Last but not least, the local political and cultural environment became fertile ground for a new generation of ambitious community leaders at both provincial and national levels who took advantage of changing circumstances to promote Ukrainian studies at the University of Alberta ( $U$ of A).

In the 1970s, the $U$ of $A$ was not in the same league as the best universities in Canada and the US, especially in the humanities. For a long time, the $U$ of $A$ was known as a purely provincial educational centre limited to local needs and practical disciplines (Zimmerman 301). Like many other North American universities, the U of A developed Slavic, East European, and Soviet studies after World War II. As in other universities, these disciplines at the $U$ of A were dominated by the new immigrants: Orest Starchuk, Yar Slavutych, Oleh Zujewskyj, Metro Gulutsan, and Bohdan R. Bociurkiw. These Ukrainian scholars contributed immensely to the development of their respective disciplines in Edmonton and across Canada (The Development of Slavonic and Soviet Studies). After Bociurkiw took up his professorship in Ottawa in 1969, and Professor Starchuk's premature death on February 14, 1971, it was Professor Gulutsan who actively promoted the establishment of an Institute of Soviet and East European studies at the $\mathrm{U}$ of A (Lupul, The Politics of Multiculturalism 160).

Several national and international conferences organized by the $U$ of A's Ukrainian scholars in the mid-1960s led to the development of the International Council for Central and East European Studies (ICCEES), an outgrowth of the Central and East European Studies Association of Canada and a similarly named society in Alberta, both of them Gulutsan's brainchild (Harasymiw, Book Review of Roots and Realities 155). In parallel, the institutionalization of Soviet and East European studies at the $U$ of A evolved from the Inter-Departmental Committee on Slavonic and Soviet Studies into the Division of East European and Soviet Studies and, later, the Department of Slavic and East European Studies. Although none of the scholars mentioned above ever raised the issue of a Ukrainian research centre or institute in Edmonton, Gulutsan indicated many times that Ukrainian topics would be central in the research agenda of any future institute. In this he was actively supported by his colleagues Lupul and Mykola Suchowersky, ${ }^{8}$ all of whom, as well as Starchuk, had regional, Bukovynian roots in common.

\footnotetext{
${ }^{8}$ A postwar émigré who worked as a librarian at the University of Alberta and was an active member of the Ukrainian Canadian Committee.
} 


\section{In SEARCH OF A CONSENSUS}

Alison Stoddard wrote, "The Ukrainians were not the largest ethnic group in the Prairie Provinces but were definitely the most vocal in demanding cultural language rights, and one of the least likely to have assimilated into the broader Anglo culture" (9). Edmonton's Ukrainian community enthusiastically embraced the B\&B Commission's recommendations to promote ethnic studies and cultures. Many local Ukrainian organizations prepared briefs for presentation to various official bodies and persons concerning the Ukrainian community's educational and cultural demands (Ukrainians in Alberta 211-12). In the autumn of 1970, the local branch of the P\&B Club (today the Ukrainian Canadian Professional and Business Association [UCPBA]) struck a committee on multiculturalism chaired by Peter Savaryn (Savaryn, "Spohady uchasnyka" 330-31). Soon he joined an informal Ukrainian professors' club established by Lupul, Gulutsan, Starchuk, and Suchowersky in early February 1971 (Lupul, "The Establishment of the Canadian Institute of Ukrainian Studies" 5). The P\&B Club and the professors' club became the two main bodies where the idea of the Canadian Institute of Ukrainian Studies was born and developed by two prominent leaders of the Ukrainian community-Savaryn and Lupul.

Savaryn (1926-2017) was a postwar émigré with Galician roots who made a successful career in Canada (Savaryn, $Z$ soboiu vzialy Ukrainu). A politician by vocation, a diplomat by nature, and a lawyer by training, he effectively represented many Ukrainian diaspora institutions in Canada, and even abroad, as a president of the National Executive of the Canadian Foundation of Ukrainian Studies (1979-83) and the leader of the World Congress of Free Ukrainians (1983-88). At the same time, he had significant influence in the leadership of the Progressive Conservative Party in Alberta. Finally, as a member of the Board of Governors of the University of Alberta (from 1972), Savaryn was well positioned to navigate the Ukrainian community and the national political and provincial academic worlds. It would be fair to emphasize that Savaryn's political and diplomatic skills made it possible to maintain a strategic alliance between earlier and postwar Ukrainian immigrants.

While Savaryn came to Canada as a conscious Ukrainian nationalist, Alberta-born (1927) Lupul, another prominent leader of the Ukrainian community in Alberta, had every reason to call himself a Canadian nationalist of Ukrainian descent, whose public career was informed by the policy of multiculturalism (Rabchenuk). Lupul perceived multiculturalism, not just as an opportunity to promote the Ukrainian national case, but as a starting point and a tool to make Canadian society more just and equal (Luciuk and Hryniuk 8). For Lupul it was not that multiculturalism was for Ukrainians in Canada, it was that Ukrainians were for Canadian 
multiculturalism. Lupul's memoirs demonstrate that he remained highly skeptical of the potential and priorities of Ukrainian immigrant institutions. $\mathrm{He}$ consistently contrasted the political "ineptitude" of the Ukrainian Canadian Committee (UCC) with the political competence of the "largely Canadian-born" P\&B Federation, which he considered "a more effective political pressure group ... to push for a policy of multiculturalism than the largely émigré-led Ukrainian Canadian Committee of that time" (Kravchenko, Ukrainian Studies in Canada: Texts and Contexts 23).

The difference between Savaryn's understanding and Lupul's understanding of the concept of "Ukrainian studies" was substantial. They favoured different ideas about the political context, the academic priorities, and the models for the institutional development of Ukrainian studies in Canada. These differences can be traced through all the stages in the development of the CIUS project. Savaryn was guided by the model of the Ukrainian Research Institute at Harvard within the framework of a panUkrainian national discourse. He maintained close contacts within the global Ukrainian intellectual diaspora, in particular with Omeljan Pritsak, Volodymyr Kubijovyč, and George Y. Shevelov, who provided ideas and suggestions for the model of the future institute.

Unlike Savaryn, Lupul, as he himself confessed, "knew very little about Ukrainian studies and not really all that much more about the study of Ukrainians in Canada" (The Politics of Multiculturalism 253). His facility in the Ukrainian language was also not advanced. Lupul believed that Ukrainian studies in Canada should primarily serve the cultural and educational needs of the Ukrainian-Canadian community. He harboured ambitious plans to "build a national educational ladder" from Ukrainian kindergarten through Ukrainian bilingual classes, "to be capped by a research and publication institute of Ukrainian studies at the university" (Kravchenko, Ukrainian Studies in Canada: Texts and Contexts 23). In other words, Lupul's goal was for the institutional completeness of the UkrainianCanadian ethnic community.

Until 1973 at least, Lupul was convinced that the U of A did not have an academic base for a centre or institute of Ukrainian studies (The Politics of Multiculturalism 240). That is why he initially advocated the inclusive concept of Ukrainian studies under the umbrella of Slavic, East European, and Soviet studies that had generally been adopted in North America. Lupul first articulated the idea of an institute of Soviet and East European studies in a brief he submitted to the B\&B Commission in 1970 on behalf of the Ukrainian Language Association, a constituent of the Modern and Classical Language Council of the Alberta Teachers' Association ("The Establishment of the Canadian Institute of Ukrainian Studies" 4-5). Later he persistently lobbied the idea of a Soviet and East European studies institute in support of his colleague and close friend, Gulutsan. 
However, from the outset Savaryn opposed Lupul's idea of a Soviet and East European studies institute, asserting, "any 'association' with the socalled 'Slavic,' and even more so 'Soviet,' studies only annoyed me" ("Spohady uchasnyka" 334-35). Savaryn was also concerned about the possible "dissolving" of Ukrainian studies within the framework of Slavic and Soviet studies. As the polemics around the HURI suggested, Savaryn was not the only one who had such misgivings. What also informed his attitude toward Gulutsan's project was purely political. Many of those involved in Slavic and East European studies favoured expansion of academic and cultural contacts with the Soviet Union. Gulutsan, for example, became a member of the Canada-USSR mixed governmental commission on academic exchanges in December 1972 (Lupul, "Metro Gulutsan" 437). In contrast, most postwar Ukrainian émigrés actively opposed any Canadian-Soviet rapprochement. This was another reason why Savaryn was determined to promote an exclusionary rather than an inclusive model of Ukrainian studies. For tactical reasons, however, he never opposed it publicly; he simply avoided any discussion of the issue with Lupul and with his own friends (Savaryn, "Spohady uchasnyka” 358).

Savaryn publicly expressed the idea of creating a Ukrainian studies centre at the $U$ of $A$ for the first time at a meeting of the Multiculturalism Committee of Edmonton's P\&B Club on April 1, 1971 (Savaryn, "Spohady uchasnyka" 334-36). The idea was included in a brief the club submitted to the provincial government on April 14, 1971 (Lupul, "The Canadian Institute of Ukrainian Studies" 90). Subsequently, the ideas about creating both a Ukrainian and a Soviet/East European institute co-existed in the briefs local Ukrainian activists presented to the provincial government. It is truly amazing how persistent Savaryn was in promoting a separate institutional model of Ukrainian studies and opposing all other alternatives. According to Lupul, "The brief, presented to the government on 14 April, consisted of five parts, with the third, 'The University and East European Studies' (drafted by Savaryn), devoting one page to an Institute of Soviet and East European Studies and three to a Ukrainian Studies Centre" ("The Establishment of the Canadian Institute of Ukrainian Studies" 6). Later, Savaryn managed to convince his partners to drop "Soviet" from the title of the would-be institute.

The tactical alliance between Savaryn and Lupul demonstrated the Ukrainian community's potency in the development of the project to establish a chair in Ukrainian history at the $U$ of $A$. Both agreed that the Ukrainian-American historian Ivan Lysiak-Rudnytsky, who happened to be a visiting professor at the $U$ of A during the 1970-71 academic year, would be the best candidate for the job. Lupul, Savaryn, and Laurence Decore (a future mayor of Edmonton), met the U of A president, Max Wyman, at the 
end of March, 1971, to discuss the issue (Decore). ${ }^{9}$ The meeting was a disappointment for the Ukrainians: Wyman openly declared that Ukraine did not exist as a country and suggested negotiating with the University of Calgary for the teaching of Ukrainian history (Khymka 103). After that, direct dialogue between the local Ukrainian community and the University of Alberta's leadership was frozen for a few years (Savaryn, "Spohady uchasnyka" 334-35).

On behalf of the Ukrainian activists, Edmonton's P\&B Club approached the provincial government with the same request (Khymka 103). This time the result was different. Alberta's politicians appeared to be much more responsive to the agenda of multiculturalism than the university's administrators were. In late April, 1971, Premier Harry Strom became one of the first Canadian politicians to speak out in favour of the policy of multiculturalism-even ahead of Prime Minister Trudeau (Woycenko 86). Local Ukrainian activists participated enthusiastically in conferences on multiculturalism organized by the provincial government (Woycenko 104). The Ukrainian community and the Alberta government quickly managed to achieve what the president of the university had initially disagreed with: in the autumn of 1971, Ivan L. Rudnytsky began his relatively short but bright career at the U of A after obtaining a joint appointment in the Department of History and the Department of Political Science (Woycenko 105). His appointment vividly demonstrated that political connections with the provincial government could be effectively used to exert pressure on university administrators.

Officially Rudnytsky became a professor of Ukrainian and East European history, but his teaching and research activities were fully devoted to the former. His arrival in Edmonton as a scholar of international reputation greatly increased the profile of Ukrainian studies at the $U$ of $A$. It is worth noting that almost immediately after this appointment, Savaryn started consultations with Pritsak and Shevelov about possible candidates to teach Ukrainian literature at the university. In parallel, in February 1972, Gulutsan, supported by Lupul, submitted a proposal to the U of A's dean of graduate studies for the creation of an East European institute (Lupul, The Politics of Multiculturalism 160).

9 I did not find any evidence in support of Per Rudling's suggestion that the participants had raised the issue of the Ukrainian institute by that time (Rudling 742). 


\section{IN SEARCH OF A FRAMEWORK}

The idea of a research institute of East European studies became the most obvious alternative to that of a Ukrainian research institute or centre. However, despite its visible academic potential, the project did not find support at the $U$ of $A$ or in the government, or in any of the relevant ethnic communities. It seems that Gulutsan and his followers made a strategic error in conceptualizing their project. Instead of emphasizing the geopolitical or epistemological potential of East European studies, which would have made room for comparative and interdisciplinary approaches, their justified motivation for such an institute was the cultural needs of the local immigrant ethnic communities. By playing to the grounds of ethnicity, this "East European" territorial concept could not compete with the separate national agendas of ethnic communities in Canada in the era of its new ethno-cultural policy of multiculturalism.

Another disciplinary alternative to Ukrainian studies could have been the recently introduced discipline of Canadian ethnic studies (Anderson, "Canadian Ethnic Studies"), the development of which had been boosted in 1965 by the first national conference on Canadian Slavs, held by Alberta scholars in Banff (Lupul, The Politics of Multiculturalism 64). The first attempt at institutionalizing ethnic studies in Canada was initiated by scholars at the University of Calgary; there, in late 1966, Professor Alexander Malycky and his colleagues in the Department of Germanic and Slavic Studies made a proposal to organize a university-level research centre devoted to the study of Canadian ethnic groups (Malycky). In 1968, the Council of the Faculty of Arts and Science at the University of Calgary voted to accept such a centre as one of the university's projects.

In 1969, a new journal, Canadian Ethnic Studies, was established at that research centre "to become an outlet for studies pertaining to Canadian Ethnic groups, conducted both in this country and abroad" (Malycky 1). The centre, as well as the Inter-University Committee on Canadian Slavs under the leadership of Professor Bida, became a basis for the creation of the Canadian Ethnic Studies Association in 1971 during a meeting dominated by Ukrainian scholars Bohdan Bociurkiw (Carleton University), Wsevolod Isajiw (University of Toronto), Senator Paul Yuzyk (University of Ottawa), and Robert Karpiak (Queen's University). Professor Isajiw became the president of the association in 1973.

The field of Canadian ethnic studies resonated well with the UkrainianCanadian community's aspirations and with research agenda in general. Lupul considered the model of an ethnic studies centre, "established within a faculty of education," to be the multiculturalism policy's best match ("The Establishment of the Canadian Institute of Ukrainian Studies" 7). As such, it would take priority over the idea of an institute of Ukrainian studies. It is 
telling that in a brief submitted to the government in early 1972 by the P\&B Club's multiculturalism committee, the idea of a Ukrainian studies centre/institute was replaced with a request for an ethnic studies centre; the brief appeared next to an article about a Soviet and East European Studies Institute (Savaryn, "Spohady uchasnyka" 343-44). The provincial government promptly expressed its support for the idea of a centre of ethnic studies (Lupul, "The Establishment of the Canadian Institute of Ukrainian Studies" 12). In 1973, as a newly appointed Canadian Consultative Council on Multiculturalism (CCCM) executive member responsible for the Prairies and Northwest Territories regions, Lupul began to consider the prospects for establishing “a 'National Institute for Canadian Ethnic Studies' in Ottawa, with provincial branches in Montreal, Toronto, and Edmonton, and possibly Vancouver and Halifax" (Lupul, "The Establishment of the Canadian Institute of Ukrainian Studies" 6).

However, the idea of a Ukrainian studies centre was not abandoned. According to Savaryn, it reappeared in the next brief, submitted by the same multiculturalism committee of the P\&B Club to the Alberta government on May 16, 1972 (Khomiak). This time, as a newly appointed member of the Board of Governors of the U of A (since April 11, 1972), Savaryn was in a better position to insist on the creation of a Ukrainian centre/institute. Moreover, the Ukrainian Canadian Committee (UCC) also took on the idea and galvanized it by preparing a scholarly conference on Ukrainian studies in Toronto (Savaryn, "Spohady uchasnyka" 352). Meanwhile, Lupul soon became disappointed with the federal government's cool attitude toward the idea of an ethnic studies centre.

As soon as Lupul became aware that neither the federal government nor the Ukrainian community was ready to financially support an institute/centre of ethnic studies, he gave up on that idea altogether. Nevertheless, until at least 1973 he remained a strong supporter of the idea of an East European institute at the U of A. After considering various options, Lupul ultimately became involved in the Ukrainian studies centre/institute project promoted by Savaryn and the UCC. Not incidentally, in his memoirs the history of the CIUS begins in 1973. I believe that such a radical change of mind on Lupul's part can hardly be attributed to the personal influence of Luckyj, as Lupul himself and his partner Savaryn have suggested (Lupul, The Politics of Multiculturalism 240; Savaryn, "Spohady uchasnyka" 348-49). The real reason behind his move seems to have been pragmatism, especially when Lupul's strong personality is taken into account. 
Lupul reconsidered his skepticism about the idea of a "particular" centre or an institute of Ukrainian studies only after he was elected president of the Canada-wide Ukrainian Canadian Professional and Business Federation (UCPBF) in May 1973, uniting the individual P\&B Clubs (Lupul, The Politics of Multiculturalism 177). As mentioned above, he considered the UCPBF to be more effective than the émigré-controlled UCC as a political instrument serving Ukrainian-Canadian needs. Under Lupul's effective leadership, the UCPBF could have replaced the UCC in the role of a national representative of the Ukrainian community in Canada (Lupul, The Politics of Multiculturalism 241; Savaryn, "Kanads'ka fundatsiia ukrains'kykh studii" 49). However, to be able to do so, the federation would have to elaborate its own agenda and build a cultural identity that would appeal to all Ukrainian stakeholders in Canada.

It became clear to Lupul that neither the East European idea nor the newly established Ethnic Studies Association could provide the federation with sufficient symbolic capital to obtain the substantial financial support required for their ambitious plans (Lupul, "The Establishment of the Canadian Institute of Ukrainian Studies" 8). But a Ukrainian studies centre/institute project could supply that symbolic capital, especially when Lupul articulated the idea of an institute of Ukrainian studies that would fulfill the role of "a single national coordinating institution that worked from clearly established priorities and discouraged duplication," rather than a local or discipline-based body (The Politics of Multiculturalism 257). He openly opposed the affiliation of a Ukrainian studies institute with any church and defended its secular character. This stance was motivated by his perceptions of both the Orthodox St. Andrew's College at the University of Manitoba and the Ottawa-based Ukrainian research institute project, which he considered to be vulnerable to Catholic influence (Lupul, The Politics of Multiculturalism 241).

Lupul's consultations with Gulutsan, Rudnytsky, Luckyj, and Bociurkiw convinced him that "if a Ukrainian centre was at all viable, it could only develop in Toronto under Luckyj's direction" (Lupul, "The Establishment of the Canadian Institute of Ukrainian Studies" 8). In the fall of 1973, the executive of the UCPBF started the process of establishing its new financial arm, the Canadian Institute of Ukrainian Studies Foundation, ${ }^{10}$ with the aim of organizing a nationwide fundraising campaign for the future Ukrainian studies institute. Thus, on January 10, 1974, the UCPBF's executive decided, after some hesitation, to make this its priority (Lupul, The Politics of

10 Renamed the Canadian Foundation for Ukrainian Studies in 1979. 
Multiculturalism 240; Savaryn, "Spohady uchasnyka" 353). It also tried to get the UCC and its regional branches involved in establishing the institute/centre for Ukrainian studies at the University of Toronto (Lupul, The Politics of Multiculturalism 240). However, the UCPBF's bold move was confronted by all other competing projects.

The UCC expressed its intention to make Winnipeg, not Toronto, the location of the future Ukrainian studies centre (Lupul, The Politics of Multiculturalism 240). The idea of a Ukrainian university in Winnipeg also appeared to be resurrected-even more so after the UCPBF elected a new leadership and relocated to Manitoba's capital, expressing support for a Winnipeg-based Ukrainian studies centre. The National Conference on Ukrainian Academic Studies in Canada, which, according to Savaryn, was supposed to be organized in Toronto, was now going to be in Winnipeg ("Spohady uchasnyka" 352). Characteristically, the Ukrainian academic community appeared even less prepared than the political leaders to articulate its position on a Ukrainian studies centre/institute. Many scholars and institutions were not directly involved in the discussions about a future institute of Ukrainian studies whose concept and profile remained unclear. ${ }^{11}$ In many cases, they were simply not well informed about the plans and projects underway.

The two-day National Conference on Ukrainian Academic Studies held April 6-7, 1974, in Winnipeg and attended by forty-seven Ukrainian scholars from eleven universities in Canada, was in fact the first such conference in Canada (University of Alberta archives, Accession No.77-129-8 J). Its participants expressed support for all the projects elaborated by competing groups of scholars from various universities in Canada, including Edmonton, Toronto, and Ottawa. One of the results of the conference was the creation of a national standing committee, headed by Ivan L. Rudnytsky, "to assist the political authorities and the federation's [UCPBF] executive" with the coordination and development of Ukrainian studies in Canada (University of Alberta archives, Accession No.77-129-8 J; Savaryn, "Spohady uchasnyka" 356). However, the committee's profile and mandate were outlined in general terms only.

In sum, for a long time, political and intellectual leaders of the UkrainianCanadian community were not able to reach a consensus on either a profile of or a location for a future centre/institute of Ukrainian studies. As before, Winnipeg and Toronto, but not Ottawa or Edmonton, remained the main contenders for such a role (Lupul, The Politics of Multiculturalism 242; Savaryn, "Spohady uchasnyka" 350, 353). Personal ambitions also

\footnotetext{
11 According to Savaryn, the Federation discussed with the provincial government the issue of an "Institute of Ukrainian Language and Literature" for the western provinces ("Klub ukrains'kykh profesionalistiv" 310).
} 
contributed to the messy situation. ${ }^{12}$ Each group of Ukrainian activists and scholars persisted in lobbying on behalf of its own project. In addition, it became obvious that neither the federal government nor leading Canadian universities were open to the idea of a centre or institute for Ukrainian studies. A consensus between political and academic priorities was much more achievable at the regional rather than the national level.

\section{ALBERTA: A REgION FOR A NATION?}

In March 1974, Savaryn started testing the waters with the Alberta government about a Ukrainian studies centre/institute. He, Lupul, and Decore initiated several meetings with government ministers-James Foster, Julian Koziak, Albert Hohol, and Bill Diachuk (Savaryn, "Spohady uchasnyka" 354; "Kanads'ka fundatsiia ukrains'kykh studii" 53). To their great surprise, the ministers expressed genuine interest in the idea of an institute of Ukrainian studies. Lupul later confessed that he was "surprised that Hohol thought enough of the project to take it under his wing, for I had never heard him speak Ukrainian or show any interest in Ukraine or Ukrainian-Canadian affairs. Nor did he reveal much interest in either in the course of pursuing the institute-idea" (The Politics of Multiculturalism 257). The same can be said about many Ukrainian Canadians. All of them were awakened with the introduction of the multiculturalism policy in the early 1970s.

Besides ethnic sentiments, something more substantial motivated provincial politicians to back a regional project. The confrontation between Alberta and the federal government in the struggle for control over the province's natural resources, which became aggravated during the global energy crisis of 1973, was perhaps of primary importance. Both sides in this complex dialogue used the policy of multiculturalism to strengthen their political influence, but sometimes it looked like the province had stronger arguments in its favour because of the support of local ethnic communities and regional solidarity (Alcantara et al.). The "Ukrainian fact" strengthened Western Canadian regionalism, in the framework of which the Prairie

\footnotetext{
12 According to Lupul, Savaryn and the Toronto-based activist Stanley Frolick were "working to outdo one other"; "[t]heir personal rivalry was soon entwined with the traditional Canadian rivalry between the young and upstart West and the experienced and more worldly East" (The Politics of Multiculturalism 249). Judging from the same source, the question arises: did Lupul's reluctance toward Yuzyk's ideas also contribute to the growing atomization of the Ukrainian-Canadian community with regard to the Ukrainian studies centre/institute issue?
} 
Provinces constantly demonstrated their alienation toward both the federal centre and Canada's eastern provinces in general (Gibbins and Berdahl 1-5).

It is interesting to note that during a meeting of Ukrainian activists and politicians that took place on March 31, 1974, in Edmonton to discuss the institute of Ukrainian studies project, some participants voiced skepticism as to possible co-operation between eastern and western political elites. They stressed that the government of Alberta "will not go with the east, as the east will not go with the west" (Savaryn, "Spohady uchasnyka" 355). The Ukrainian MLAs, in turn, suggested that the institute should be established in one of the western provinces and not in Toronto (Savaryn, "Kanads'ka fundatsiia ukrains'kykh studii" 54; Lupul, The Politics of Multiculturalism 243). However, each of the four western provinces pursued its own distinctive interests, which overcame regional solidarity (Friesen xv). Edmonton very soon became the main pretender to the role of capital of Ukrainian studies in Canada.

After further consultations with members of Alberta's Cabinet of Ministers, Lupul and Savaryn prepared a "Proposal for an Institute of Ukrainian Studies in Western Canada," which they submitted to the minister of advanced education, James Foster, on behalf of the UCPBF on April 11, 1974 (University of Alberta Archives, Accession No.77-129-8 J). This document was perhaps the first attempt at articulating in detail the main ideas about the profile and mandate of a future institute of Ukrainian studies in Canada.

In the proposal, the Ukrainian people were presented as an "endangered species" whose culture was threatened with complete disappearance due to Russification in the USSR and Anglo-American assimilation in Canada. In this respect, they were likened to the Franco-Canadians, indigenous peoples, and people from the Baltic nations. Here, the discourse prioritized UkrainianCanadian rather than pan-Ukrainian: "The particular orientation of the Institute would be the study of the 'Ukrainian fact' in Canada, with particular emphasis on the preparation of personnel able to meet the growing needs of ... the Ukrainian-Canadian community as a whole" (University of Alberta Archives, Accession No.77-129-8 J). Although the CIUS project was put in the framework of a regional, western Canadian initiative, the authors of the project emphasized the national status of the future institute as well as its inter-university function.

In terms of disciplinary profile, the project looked more innovative than the classical Harvard model. Unlike the latter, the former was based on a broader understanding of Ukrainian studies, including not only the core humanities but also socio-political disciplines: "An Institute of Ukrainian studies would need to have access to undergraduate courses not only in language and literature but in the teaching of Ukrainian as a second language, history, political science, sociology, the fine arts, and the history of 
Ukrainians in Canada" (University of Alberta Archives, Accession No.77-129$8 \mathrm{~J})$. In other words, the authors of the project envisioned an "exclusive" or, as Lupul put it, "particularistic" —institutional model of Ukrainian studies (which he did not accept earlier).

Lupul admitted later that the project was "sketchy" and "drawn up hastily," its aim and professional agenda "poorly developed," and the budget proposal (CAD \$310,500) practically "plucked out of the air" (The Politics of Multiculturalism 245, 254). Nevertheless, the project was formally submitted to the provincial Cabinet, from where it was redirected to the University of Alberta. In mid-October, 1974, the project was forwarded to the university's Academic Development Committee (ADC), where it was discussed for about eighteen months (Savaryn, "Spohady uchasnyka" 360). Meanwhile, Lupul, Rudnytsky, and Savaryn agreed on important issues that gave the project greater clarity. They adopted the name "Canadian Institute of Ukrainian Studies for its greater campus appeal and to differentiate it better from the Ukrainian Research Institute at Harvard, in existence since June 1973" (Lupul, The Politics of Multiculturalism 247). According to Lupul, they also agreed "that Rudnytsky would direct the institute 'on a part-time basis' (at his request), and I would be his associate. The subject was not an issue; I was not in Ukrainian studies and had no academic base to run such an institution" (The Politics of Multiculturalism 247). Very soon, however, Lupul had to change his mind once again.

\section{THE INSTITUTE IS BORN}

The first round of debates over the Canadian Institute of Ukrainian Studies (CIUS) project started in October 1974 and lasted until the end of June 1975. They reflected a wide range of views that, to a certain extent, enable us to understand the mood and feelings of the university community in the face of the new political and cultural challenges of the 1970s. Members of the ADC considered the CIUS project to be a community request that originated outside the campus. It "was greeted coolly by many on campus because it was seen as an example of the provincial government imposing its priorities on the university" (Macleod and McGuckin 244). The most eloquent of the members reminded each other that "the University had never set up an institute on a 'from top down' basis .... groups should be encouraged to begin on the basis of informal association .... Thus, the granting of a formal structure was usually the second or third step. The first was to encourage the formation of a group" (University of Alberta Archives, Accession No.77129-8 K).

The ADC expressed overt skepticism about academic legitimization of the "ethnics" in general. To some skeptics, the academic quality of the CIUS 
project was suspect. It was carefully wrapped in rhetoric about the university's mission to cultivate knowledge "instead of to promote and preserve the culture of a specific ethnic group" (University of Alberta Archives, Accession No.15 May 1975, 77-129-9 I). The culture vs knowledge antinomy revealed an obvious collective phobia on the part of the academic establishment-already haunted by the apparition of the Ukrainian "ethnic mafia"-about a possible "flood of ethnic institutes which in no way reflect the 'legitimate' priorities of the university" (Slavutych, U vyri bahatokul'turnosty 32). As Lupul put it, "The fear is that other [ethnic] groups will ride the coattails of the Ukrainians, like we are trying to do with the French" ("The Establishment of the Canadian Institute of Ukrainian Studies" 8-9). The dean of graduate studies, Professor J. R. McGregor, would subsequently articulate the same fear in a more explicit form (Savaryn, "Spohady uchasnyka" 376-77). Such feelings and rhetoric became widespread among Canadian political and academic elites who were poorly informed about the meaning of ethnic studies as an academic discipline (Harasymiw, "Comments").

By the same token, the $U$ of A faculty appeared to be poorly equipped to recognize the nuances of Ukrainian studies. In particular, Ukrainianoriented disciplines had not evolved into coherent area studies, but instead belonged to various disciplines and institutions. The Harvard example showed, moreover, that modern Ukrainian studies are not wholly compatible with Slavic studies. However, the Harvard Ukrainian Research Institute (HURI) was not even mentioned during the ADC meetings. In searching for alternatives to the institute proposal, some ADC members came up with the idea of an "Institute of Cultural Contributions" or a "multicultural institute" (University of Alberta Archives, Accession No. 77 129-9 I, Ref. R65). No further definition or explanation was provided. The vague intention was perhaps to bring these and possible future "ethnics" into one institution and let that institution deal with them. It is telling that no one in these deliberations brought forward a real alternative to the CIUS project. The idea of an institute of East European studies, as had been promoted by Gulutsan, could have blocked the CIUS project, as Lupul rightly noticed. However, as it happened, it was not discussed.

After some time, the ADC members abandoned the idea of a "multicultural institute," whatever it meant, and replaced it with the more realistic idea of an institute of Canadian-Ukrainian studies, giving the latter clear priority over the pan-Ukrainian perspective: "It has been agreed that the Canadian emphasis was to be recommended, i.e., a principal aim of the Institute would be to study the Ukrainian ethnic group within Canada, as opposed to studying it in isolation from the Canadian matrix" (University of Alberta Archives, Accession No. 77-129-9 I, 15 May 1975). Put differently, "the Institute should be concerned with Canadian-Ukrainian studies rather 
than Ukrainian studies per se, and that the title should so indicate-e.g., 'Institute of Canadian-Ukrainian Studies'" (University of Alberta Archives, Accession No. 77-129-9M, 15 May 1975; 27 June 1975). It is difficult to say from where or from whom such an idea arrived to the committee, but it had an important influence on the further course of events.

The ADC members appeared to have a better understanding of the mission and disciplinary aspects of the CIUS project. In their opinion, it "fell midway between an Institute, as the University would define one, and a teaching department ... what was desired was an autonomous Institute situated on the Campus, but with responsibilities extending beyond the University and the Province" (University of Alberta Archives, Accession No.77-129-8J, 14 November 1974). Thus, the issue of the future institute's mutual relations with existing university institutions was considered: "Whether the Institute should be associated with the Faculty of Arts, as an offshoot of one of its departments, or a parallel structure to the Soviet and [East European] Studies Division ... or whether it should be associated with the Faculty of Graduate Studies and Research" (University of Alberta Archives, Accession No.77-129-9 I, 15 May 1975). Clarification was needed as to the relationship with the centre in Toronto, to say nothing of other specifics such as its premises and the library. The structure of the CIUS as well as its profile remained unclear and debatable.

Despite its overt skepticism, the committee did not dare block the CIUS project, which already had support at the highest level of the university administration. The committee was too weak to withstand political pressure from the outside and bureaucratic pressure from the inside. It is telling that the ADC members did not even use the term "academic autonomy" during their debates. The provincial government's strategy, implemented by the two ministers of education-Julian Koziak and Albert Hohol, both of whom were of Ukrainian origin - "severely limited the $U$ of A's freedom of action in setting its research and teaching priorities" (Macleod and McGuckin 231). Of no less importance was the fact that the government's growing financial resources did not mean substantially better funding for the university. As a result, "After considerable discussion, the Academic Development Committee, in the spring of 1975, endorsed in principle the proposal which had been forwarded by the government ... if assurances of financial support were received from the Government" (University of Alberta Archives, GFC on 31 May 1975, p. 251).

It became apparent that the ADC's recommendations about Canadianoriented research priorities over pan-Ukrainian ones opened the possibility for Lupul to lead the CIUS project. Several months before the ADC endorsement, Lupul had critically assessed the level of his professional training in the field of Ukrainian studies and gave the lead in this case to Ivan L. Rudnytsky. Now, when the CIUS project was becoming real, and especially 
as it acquired a Ukrainian-Canadian profile, Lupul expressed his willingness to lead the project (The Politics of Multiculturalism 253; Savaryn, "Spohady uchasnyka" 372). Unquestionably, Lupul, a native Albertan with broad connections and public experience, was better prepared to serve as an administrator than Rudnytsky. However, in this case it was not just a choice between two very different personalities: it was also a choice between the profile and research priorities of the future institute. It was Lupul, then, who played a major role in the final stage of the debates over the CIUS's profile, status, and place in the U of A's structure.

In the autumn of 1975, Meyer Horowitz, vice-president (academic) of the $U$ of A, appointed an ad hoc committee consisting of Drs. Brian Evans, Metro Gulutsan, Madeline Monod, and Thomas Priestly, chaired by Lupul, to prepare a detailed proposal for establishing the CIUS (Lupul, The Politics of Multiculturalism 252). Lupul, following the ADC's recommendations, reworked the project with the assistance of Luckyj and Bociurkiw; he involved the latter because "he was in political studies and (having lived in the west) had a better understanding of western Canada than Luckyj and could be relied upon to support my emphasis on Ukrainian-Canadian studies" (Lupul, The Politics of Multiculturalism 260). In Lupul's words, "In drawing up the proposal, I saw CIUS and the bilingual classes as the first step in institutionalizing multiculturalism, similar to the institutionalized FrenchEnglish bilingualism then being created by the federal government" (Kravchenko, Ukrainian Studies in Canada: Texts and Contexts 23). Hence the Ukrainian-Canadian theme was emphasized over the pan-Ukrainian one, while community-oriented issues seemed to dominate fundamental research. Lupul appeared to be reluctant to involve Yuzyk and Kubijovyč, who had volunteered to contribute to the debates, while seemingly also excluding Rudnytsky.

In its final version, the CIUS project was submitted to the ADC for reexamination in February 1976. The circumstances of its implementation could not have been better: Horowitz, the former dean of education, who had personal connections with Lupul, had become the new vice-president (academic) of the U of A and chair of the ADC. Like his predecessor Henry Kreisel, he expressed full support for the CIUS project. Opposition to the CIUS project continued at the university: it included George Baldwin, dean of the Faculty of Arts; Tom Priestly, chair of the Department of Slavic Languages; and J. G. McGregor, dean of the Faculty of Graduate Studies and Research. However, none of them had a real alternative to the CIUS project that could be seen as the academic community's answer to the policy of multiculturalism. 
On April 29, 1976, the ADC passed the CIUS project, with certain conditions. ${ }^{13}$ The project was approved by the U of A General Faculties Council on May 31 and by the Board of Governors on June 18 (Savaryn, "Spohady uchasnyka" 366). Lupul was appointed director of the CIUS. The institute's annual budget-CAD $\$ 350,000$ - established by a grant from the provincial government-was "the largest public grant that any Ukrainian community project had hitherto received outside Ukraine" (Lupul, The Politics of Multiculturalism 256). Later, it was increased to CAD $\$ 500,000$. One of the conditions for approving the CIUS project was a probationary term of three years, after which a re-examination of the institute's activities was intended. In the spring of 1979, U of A leadership created a special commission for a comprehensive review of the CIUS (Savaryn, "Spohady uchasnyka" 379). It proceeded without controversy, and its verdict was formulated exclusively in positive terms: "The Institute would appear to have established a solid base of which this University can be proud, and to have a promising future which should continue to be encouraged by the University of Alberta and the Province" (Canadian Institute of Ukrainian Studies Newsletter 2).

The government's financial support was perhaps the most important condition on which the academic community agreed to include the new institute in the university structure. In 1979, at Lupul's request, the annual grant from the provincial government was transferred to the $\mathrm{U}$ of $\mathrm{A}$, "for better or worse," according to Jim Horsman's ${ }^{14}$ remarks (Savaryn, "Spohady uchasnyka" 380). As Mykhailo Marunchak indicated, "the University's acceptance of the institute involves neither an expressed nor implied commitment to absorb any part of the Institute's budget if the Cabinet, at a subsequent date, chooses to reduce or to eliminate its special funding provisions for the Institute" (736). Thenceforth, the CIUS could be considered an integral part of the $\mathrm{U}$ of $\mathrm{A}$.

It was not by accident that Lupul often recalled the French-Canadian example with regard to the Ukrainian case. A "Proposal to establish an Institut de Recherche Francophone de l'Ouest Canadien" arrived at the U of A almost simultaneously with the Ukrainian proposal. "The request came

13 "That the institute operate on 'strict observation' of university policies governing staff, space and courses; that the government understand that the university assumed no responsibility for the institute's budget; that joint appointments with the institute 'may' not be possible without additional departmental funding; that there be 'further examination' of the institute's proposed inter-university (i.e., off-campus) activities; and that 'the Director and Advisory Committee' report to the ADC after the first and second years, with 'a more complete evaluation' at the end of the third year" (Lupul, The Politics of Multiculturalism 254).

14 Minister of Advanced Education and Manpower of Alberta, 1979-82. 
from a group at the Collège universitaire Saint-Jean, and the similarity lay in that this Proposal had dealt with an Institute for Franco-Albertans"; accordingly, "the Institute would conduct studies and involve the University intellectually in the French fact" (University of Alberta Archives, Accession No.77-129-8J, R65). In 1976-77 the Collège Saint-Jean became a full faculty at the University of Alberta. This was a vivid example of the institutionalization of ethnic studies as outlined in the B\&B Commission's recommendations. There were obvious parallels between the Ukrainian and French-Canadian proposals. Ultimately, however, the U of A chose different paths for them.

The CIUS appeared as an innovative, even unique, institution in terms of its mandate, structure, and research agenda. The organizational structure underlined its claims to become an "institution, unrestricted by geography or by parochial support (religious or ideological)" (Lupul, "The Establishment of the Canadian Institute of Ukrainian Studies" 9). Two newly created bodies - the Canadian Foundation for Ukrainian Studies and the Council of Associates of the CIUS-were designed to support its national status and co-ordinating role in Ukrainian studies in Canada. The Council of Associates consisted of anywhere from 36 to 38 members, "all full professors or the most senior personnel engaged in Ukrainian studies at a particular [Canadian] university" (Lupul, "The Canadian Institute of Ukrainian Studies" 102). In fact, the Council of Associates consisted of members of the standing Conference on Ukrainian Studies that was established in April 1974 in Winnipeg; its president, Rev. Professor Alexander Baran of the University of Manitoba, became a member of the Advisory Council. CIUS's academic journal, initiated and edited by Luckyj, was projected as a national or even international forum for graduate students in Ukrainian studies ("Editorial Note"). In fact, the CIUS was supposed to play the role of a Canadian association of Ukrainian studies.

It was not easy for the $U$ of $A$ to accommodate the newly established unit, which did not fit into any existing structure or discipline and therefore required a special structure. The CIUS Advisory Council was established to co-ordinate all of the Ukrainian-related activities of the various institutions at the $U$ of $A$. The advisory council included representatives from the Division of Eastern European and Soviet Studies (Dr. Metro Gulutsan), the Department of Slavic Languages (Dr. Thomas M. S. Priestly), the Department of Secondary Education (Dr. Madeleine J. Monod), and a librarian for Slavic and East European Studies (Dr. Celestin [Mykola] Suchowersky). Given the priorities of CIUS's leading members, the Faculty of Education, the Department of Political Science, and the Division of East European and Soviet Studies became the institute's main partners within the university (Lupul, "The Canadian Institute of Ukrainian Studies" 93, 102). The interdisciplinary nature of the CIUS's academic activity was emphasized, in particular, by the 
fact that the institute was under the jurisdiction of Dr. Gerald S. H. Lock, the dean of interdisciplinary studies.

Contrary to recent opinion (e.g., Satzewich 126), the CIUS did not copy the Harvard Ukrainian Research Institute (HURI)'s institutional model. Rudnytsky correctly wrote that

the Canadian institute will have a different profile than the Harvard one. In terms of teaching, its main task will not be training professional scholars but serving the cultural needs of the Ukrainian ethnic group in Canada. In terms of publishing, we want to publish not original monographs, but course literature: textbooks, directories for university-level education, Ukrainian Canadiana, as well as something from the Sovietology. (Kravchenko, "Lystuvannia" 231; trans. Ksenia Maryniak)

The CIUS's ambitious agenda included not only Ukrainian-Canadian and pan-Ukrainian topics, but also community-oriented activities related to education and culture. As Lupul put it, "the Institute as the cap on the educational ladder will hopefully carry us through the next crisis and perhaps even avert future ones" ("The Establishment of the Canadian Institute of Ukrainian Studies" 14). It remained to be seen if the CIUS would be able to meet all expectations at local and national levels.

The CIUS embraced both Ukrainian-Canadian and pan-Ukrainian research agendas. Its dual research profile was fixed at the executive level. The director, Lupul, who specialized in Canadian studies, was assisted by two non-salaried associate directors, one at the $U$ of $A$ responsible for research-Rudnytsky ${ }^{15}$-and the other at the University of Toronto responsible for publications - Luckyj-both of whom were specialists in Ukrainian studies. Their own plans and activities were supported with financial resources and assistants. Contrary to Lupul's initial attitude that "money originating with the Alberta Government could under no circumstances be used for financing of teaching positions in other provinces," Savaryn managed to convince his colleagues and partners that the CIUS could sponsor projects conducted by scholars both in Canada and abroad (Lupul, "The Establishment of the Canadian Institute of Ukrainian Studies" 15). That opened the door for the CIUS to become a leader in global Ukrainian studies.

\footnotetext{
15 Rudnytsky resigned in 1979 either because of the differences between himself and Lupul in character and upbringing (Khymka 111) or because of fundamental disagreements with Lupul about the CIUS's priorities; possibly both conditions fostered his resignation.
} 


\section{CONCLUSIONS}

"Unexpected primacy" is one possible way of describing the CIUS's establishment in Edmonton. ${ }^{16}$ Its history was not predetermined; it was an outcome of many, sometimes contradictory, trends and circumstances rather than one triumphant campaign. At the time (1970s), Winnipeg and Toronto were the main pretenders for the status of the capital of Ukrainian studies in Canada. As with the establishment of the Mennonite University in Winnipeg and the Collège universitaire Saint-Jean in Edmonton, the idea of a Ukrainian university in Canada, even in limited form, was not completely unrealistic, especially bearing in mind the new affirmative actions initiated and conducted by the federal government in its implementation of multiculturalism. However, the idea of a Ukrainian university, or even a college, never came to fruition. It was effectively blocked by the competing trends and groups within the Ukrainian community and produced only the Centre for Ukrainian Canadian Studies at the University of Manitoba in 1981.

The same can be said about the idea of a "Ukrainian Canadian Harvard" at the University of Toronto. Lupul was "fairly certain" that "the émigrés in the east, having generously donated to Harvard, would likely have brought something into being," meaning a research institute (The Politics of Multiculturalism 256-57). However, the ambitious idea of the institute resulted only in the Chair of Ukrainian Studies at the University of Toronto, established in 1980. Of course, it was not an equivalent to the HURI. Neither was the Ukrainian Studies and Research Endowments (USRE) at the University of Ottawa (since the 1980s) the same as the Ukrainian studies centre Senator Yuzyk and his colleagues envisioned; and this list can go on. Thus, contrary to Peter Jacyk's suggestions, the Ukrainian community in Canada kept creating small academic units that competed with each other for limited resources rather than consolidating them into one strong national teaching and research institution.

The founding fathers of the CIUS never denied that, as Lupul put it, "the Institute... was absolutely a political act" (Kravchenko, Ukrainian Studies in Canada: Texts and Contexts 36); "an act of public policy made possible by the funds that the government made available" (Lupul, The Politics of Multiculturalism 256). Savaryn also confessed that "there is no need to conceal the truth-the CIUS has been established thanks to the government of Alberta" (Z soboiu vzialy Ukrainu 76). It was Canadian multiculturalism combined with pan-Ukrainian nationalism and Western-Canadian regionalism that created favourable political conditions for the emergence of the CIUS in Edmonton.

16 I borrowed this definition from an article written by Ukrainian scholars (Diatlov and Kovalenko) on the history of Kharkiv University in 1805. 
The CIUS was conceived, first and foremost, as an instrument for the implementation of the policy of multiculturalism on behalf of Ukrainian Canadians. Its principal aims were "the study of the Ukrainian people in Canada" and their cultural and educational needs (Lupul, "The Canadian Institute of Ukrainian Studies" 105). The Ukrainian-Canadian community considered the CIUS to be an institution designed to "retain and develop Ukrainian-Canadian culture" (Luciuk and Hryniuk 9). For Lupul, the CIUS became "a fine tribute to the first Ukrainian settlers who had done so much to open up the Prairies," a symbol of Ukrainian-Canadian "pioneer" mythology, and a Canadian answer to American cultural imperialism (Lupul, The Politics of Multiculturalism 256; Mycak; Lalande 51-53).

Savaryn was the only person who had envisioned the CIUS and worked consistently on its implementation from the outset. For him, the CIUS became an answer to the Russification of Soviet Ukraine and to Soviet imperialism. Savaryn did his best to align the timing of the CIUS's establishment with the 100th anniversary of the Ems Ukase of Tsar Aleksandr II (1876), which prohibited the use of Ukrainian as a literary language in the Russian Empire (Savaryn, "Spohady uchasnyka" 370). Pritsak had used the same symbolic argumentation when he called for the necessity of the HURI, which arose in response to the suppression of Ukrainian scholarship and culture in the USSR (Pritsak, "Ukrainian Studies" 63). As Kubijovyč stated in a letter to Savaryn, "it must be taken into account that the role of the institute [CIUS] is much larger than research on 'Canadian Ukrainians' - it has an all-Ukrainian significance; it must respond to all the terrible deeds that the damned Russian Bolsheviks have done to Ukrainian culture" (Savaryn, "Spohady uchasnyka" 378).

The CIUS's founding fathers tried to combine an academic agenda and a political agenda, elaborated within both pan-Ukrainian and UkrainianCanadian discourses. This compromise, and a fruitful dialogue between the Ukrainian Canadians and postwar Ukrainian émigrés, assured that the primacy of Ukrainian-Canadian topics did not exclude pan-Ukrainian topics from the CIUS's research agenda. However, the two topics did not merge into a new synthesis; and the understandings of the Ukrainian Canadians and postwar Ukrainian émigrés regarding the meaning of Ukrainian studies and the institution's priorities remained diverse. Differences in interpretation of the meaning of "Ukrainian studies" made the CIUS's research priorities the subject of many debates.

The circumstances under which the CIUS entered the $U$ of $A$, as well as its broad agenda and multidisciplinary profile, posed challenges for both the institute and the university. The establishment of the CIUS in spite of the opposition of local faculty, can be seen as a gradual evolution in the Canadian university environment and its readiness to meet new challenges, or as a weakness of the university corporation, unable to defend its academic 
autonomy against political pressure. The non-Ukrainian faculty of the U of A was not ready to appreciate the intellectual potential of Ukrainian studies; according to many of them, Ukrainian studies served only the ethnic community's cultural needs. At least some of the academics perceived the CIUS to be serving "culture" rather than "knowledge." It should be admitted that the documents articulating the necessity and concept of the CIUS did emphasize political and cultural issues over academic ones. It became a task for the first generation of CIUS scholars to legitimize Ukrainian studies as a respectable academic enterprise and to set the ratio of community-related "applied scholarship" to more strictly academic projects.

The Alberta government's grant was large enough to jump-start the institute, but in the long run it remained to be seen whether the CIUS's resources-not only financial, but also political and intellectual-were sufficient to support its claims of becoming the sole co-ordinating centre for Ukrainian studies in Canada. The fact that the CIUS was not a subject of public discussion, even within the Ukrainianist community, made it difficult for some scholars to acknowledge its role as the national co-ordinator of Ukrainian studies. Respectable immigrant research institutions like the Ukrainian Free Academy of Sciences (UVAN) and the Shevchenko Scientific Society of Canada (NTSh-K) were not invited to participate in the process of elaborating the CIUS's makeup and priorities, nor were Ukrainian professors elsewhere at the $U$ of A, to say nothing of many other Ukrainian intellectuals. Attempts at establishing a single co-ordinating structure of Ukrainian scholars involved in research and teaching at the national level were never fully successful and often remained on the drawing board (Rozumnyj, "UVAN in Canada" 123).

The Ukrainian-Canadian and global Ukrainian diaspora greeted the new institution with enthusiasm. The Ukrainian-American newspaper Svoboda even proclaimed this event "the beginning of a new era not only for the bright development of [Ukrainian] studies in Canada, but also for the development of the Ukrainian people in general" (Khomiak). Predictably, Soviet watchdogs, unable to recognize many nuances in Ukrainian-Canadian community life, put the newly established institute on a blacklist of "antiSoviet" organizations (Facts of History 620-23). This was predictable, because Soviet observers had already included Lupul, Rudnytsky, Bociurkiw, and representatives of the new postwar generation of Ukrainian-Canadian activists and intellectuals on the long Soviet list of "Ukrainian bourgeois nationalists."

There is no doubt that the CIUS was one of the most important achievements of the Ukrainian community in Canada after World War II. When the issue of its creation became a subject for debate, only a few people believed that Edmonton would be the best place for it. The process of the CIUS's establishment in Edmonton-which lasted for about five years, from 
the appearance of the idea (April 1971) to the official opening of the institute (June 1976) - was neither predetermined nor straightforward. It was full of different, even competing ideas, projects, hesitations, and coincidences. It would take some effort to integrate the CIUS into the western Canadian academic environment and to achieve organizational and financial sustainability.

\section{Works Cited}

"Agenda/Minutes and Related Materials of the Academic Development Committee." University of Alberta Archives, 1974-76.

Alcantara, Christopher, et al. 'Canadian First Ministers' Conferences and Heresthetic Strategies: Explaining Alberta's Position on Multiculturalism at the 1971 Victoria Conference." Journal of Canadian Studies/Revue d'études canadiennes, vol. 48, no. 2, 2014, pp. 99-121.

Anderson, Alan B. "Canadian Ethnic Studies: Traditional Preoccupations and New Directions." Journal of Canadian Studies/Revue d'etudes canadiennes, vol. 17, no. 1, Spring 1982, pp. 5-15.

Anderson, Brooke. "The Elephant in the (Class)room: The Debate over Americanization of Canadian Universities and the Question of National Identity." Studies by Undergraduate Researchers at Guelph, vol. 4, no. 2, 2011, pp. 5-11.

Antonovych, Marko, editor. 125 rokiv kyivs'koi ukrains'koi akademichnoi tradytsii, 1861-1986. Ukrains'ka Vil'na Akademiia Nauk, 1993.

Atamanenko, Alla. Ukrains'ke istorychne tovarystvo: idei, postati, diial'nist' (19651991). Natsional'nyi universytet “Ostroz'ka Akademiia,” 2010.

Bell, Edward. "The Rise of the Lougheed Conservatives and the Demise of Social Credit in Alberta: A Reconsideration." Canadian Journal of Political Science/ Revue canadienne de science politique, vol. XXVI, no. 3, 1993, pp. 455-75.

Berezkina, Valentyna. "Vydavnycha dial'nist' Kanads'koho instytutu ukrains'kykh studii." Bibliotechnyi visnyk, vol. 4, 2010, pp. 63-68.

Bociurkiw, Bohdan R. "Vladimir J. Kaye (Kysilewsky) (1896-1976)." Canadian Slavonic Papers/Revue Canadienne des Slavistes, vol. 18, no. 3, 1976, pp. 376-77.

Buyniak, Victor O. "Fifteen Years of Official Multiculturalism in Canada: Its Impact on Heritage Languages and Cultures." Hungarian Studies Review, vol. XIII, no. 2, Fall 1986, pp. 75-80.

Canadian Institute of Ukrainian Studies Newsletter. Vol. 3, no. 3, 1979.

Champion, C. P. “'Courting 'Our Ethnic Friends': Canadianism, Britishness, and New Canadians, 1950-1970." Canadian Ethnic Studies, vol. 38, no. 1, 2006, pp. 23-46.

Cochrane, Christopher, and Andrea Perrella. "Regions, Regionalism and Regional Differences in Canada." Canadian Journal of Political Science, vol. 45, no. 4, 2012, pp. 829-53.

Conrad, Margaret. "A Brief Survey of Canadian Historiography." New Possibilities for the Past: Shaping History Education in Canada, edited by Penney Clark, UBC P, 2011, pp. 33-54. 
Cormier, Jeffrey J. "The Canadianization Movement in Context." Canadian Journal of Sociology/Cahiers canadiens de sociologie, vol. 30, no. 3, 2005, pp. 351-69.

Darevych, Dariia. "Do istorii NTSh v Kanadi." Zahidn'okanads'kyi zbirnyk, vol. 7, Kanads'ke Naukove Tovarystvo imeni T. Shevchenka, 2014, pp. 154-76.

Decore, Laurence. "The Ukrainian Community of Alberta: An Address." Roots and Realities among Eastern and Central Europeans, edited by Martin Louis Kovacs, Central and East European Studies Association of Canada, 1983, pp. 242-43.

The Development of Slavonic and Soviet Studies at the University of Alberta in Edmonton during the Years 1964-1969: Memorandum. Inter-Departmental Committee on Slavonic and Soviet Studies, 1964.

Diatlov, Volodymyr, and Oleksandr Kovalenko. "Nespodivana pershist', abo do pytannia pro peredistoriiu zasnuvannia Kharkivs'koho universytetu." Drevnosti, 1995, pp. 88-90.

Dombrowskyi, Olexander. Book review of Chomu katedry ukrainoznavstva $v$ Harvardi? Vybir statei na temy nashoi kul'turnoi polityky (1967-1973), by Omeljan Pritsak, Ukrains'kyi istoryk, no. 1-2 (45-46), 1975, pp. 144-47.

Duravetz, G. N. Honourable Senator Paul Yuzyk: 15 Years of Service. Ukrainian Professional and Business Association, Ottawa Branch, 1978.

"Editorial Note." Journal of Ukrainian Graduate Studies, vol. 1, no. 1, Fall 1976, p. 2.

Elton, David K., and Arthur M. Goddard. "The Conservative Takeover 1971." Society and Politics in Alberta. Research Papers, edited by Carlo Caldarola, Methuen Publications, 1979, pp. 49-72.

Facts of History. Archival Documents on Relations between Ukraine and the UkrainianCanadian Community Late 1940's-1980's. Book 1, In-t istorii NANU, 2003. Ukraine-Canada: History and Modern Times.

Friesen, Gerald. The West: Regional Ambitions, National Debates, Global Age. Penguin Books, 1999.

Gibbins, Roger, and Loleen Berdahl. Western Visions, Western Future: Perspectives on the West in Canada. 2nd ed., Broadview Press, 2003.

Gregorovich, Andrew. Ukrainian Toronto: A Directory of Ukrainian Cultural Groups, Organizations and Institutions in Toronto. 2nd ed., Ukrainian Canadian Committee Toronto Branch, 1976.

Harasymiw, Bohdan. Book review of Roots and Realities among Eastern and Central Europeans, by Martin L. Kovacs, editor. Canadian Ethnic Studies/Etudes Ethniques au Canada, vol. 15, no. 2, 1983, p. 155.

---. "Comments on the Article by Per A. Rudling, 'Multiculturalism, Memory, and Ritualization: Ukrainian Nationalist Monuments in Edmonton, Alberta."' Nationalities Papers: The Journal of Nationalism and Ethnicity, vol. 40, no. 2, 2012, pp. 295-302.

Karpyak, Victoria, compiler. Senator Paul Yuzyk, 1913-1986. Father of Multiculturalism. UCC, 2017.

Keenan, Edward L. “Omeljan Pritsak (1919-2006).” Kritika: Explorations in Russian and Eurasian History, vol. 7, no. 4, Fall 2006, pp. 931-36.

Khomiak, M. "Adv. Petro Savaryn, initsiator Kanads'koho instytutu ukrains'kykh studii, z"iasovuie istoriiu tsioho instytutu." Svoboda, no. 179, 23 Sept. 1976. 
Khymka, Ivan (John-Paul Himka). "Istoriia Ukrainy ta ukraintsiv u Kanadi u viddili istorii ta klasyky Al'berts'koho universytetu." Zakhidn'okanads'kyi zbirnyk, vol. 3, Kanads'ke Naukove Tovarystvo imeni T. Shevchenka, 1998, pp. 99-119.

Klid, Bohdan, and Myroslav Yurkevich, editors. CIUS 1976-2006: 30 Years of Excellence. CIUS, 2006.

Kohut, Zenon. "KIUS u dobu nezalezhnoi Ukrainy." Zakhidn'okanads'kyi zbirnyk, vol. 3, Kanads'ke Naukove Tovarystvo imeni T. Shevchenka, 1998, pp. 78-99.

---. "Two Decades of Scholarship and Service: Report on the Canadian Institute of Ukrainian Studies (1992-2012)." East/West: Journal of Ukrainian Studies, vol. 5, no. 1, 2018, pp. 9-37. DOI:10.21226/ewjus368.

Kondra, Petro. Ukrainian Canadian Committee, Ukrainian Canadian Congress: A Review of Half Century of Community Leadership. Ukrainian Canadian Congress, 1993.

Kordan, Bohdan. Ukrainian Canadians and the Canada Census, 1981-1996. Heritage Press, 2000.

Kravchenko, Volodymyr. "Lystuvannia Romana Shporliuka z Ivanom LysiakomRudnyts'kym i Iuriiem Shevel'ovym (1962-1982 rr.)." Skhid-Zakhid: Istorykokul'turolohichnyi zbirnyk, vols. 9-10, 2008, pp. 208-94.

---. "Ukrainian Historical Writing in Canada after the Second World War." Storia della Storiografia, vol. 69, no. 1, 2016, pp. 111-28.

---. "Ukrainian Historical Writing in North America during the Cold War." East and Central European History Writing in Exile 1939-1989, edited by Maria Zadencka et al., Brill/Rodopi, 2015, pp. 93-119.

---, editor. Ukrainian Studies in Canada. Texts and Contexts: Proceedings of the CIUS Fortieth Anniversary Conference, 14-15 October 2016. CIUS P, 2018.

Kravchuk, Petro. Ukraintsi v istorii Vinnipeha. Kobzar, 1974.

Lalande, Julia. "The Roots of Multiculturalism-Ukrainian Canadian Involvement in the Multiculturalism Discussion of the 1960's as an Example of the Position of the 'Third Force."' Canadian Ethnic Studies, vol. 38, no. 1, 2006, pp. 47-64.

Laurendeau, André, and Patricia Smart. The Diary of André Laurendeau: Written during the Royal Commission on Bilingualism and Biculturalism, 1964-1967. J. Lorimer, 1991.

Luciuk, Lubomyr Y. Searching for Place: Ukrainian Displaced Persons, Canada, and the Migration of Memory. U of Toronto P, 2000.

Luciuk, Lubomyr, and Stella Hryniuk, editors. Multiculturalism and Ukrainian Canadians: Identity, Homeland Ties, and the Community's Future. U of Toronto P, 1993.

Luts'kyi, Iurii. “Kanada—za i proty: notatky anty-emigranta." Suchasnist', vol. 6, 1969, pp. 70-74.

Lupul, Manoly. "The Canadian Institute of Ukrainian Studies at the University of Alberta." Journal of Ukrainian Graduate Studies, vol. 1, no. 1, 1976, pp. 90-105.

---. "The Establishment of the Canadian Institute of Ukrainian Studies at the University of Alberta: A Personal Memoir." Canadian Ethnic Studies Journal, vol. 26, no. 2, 1994, pp. 88-111.

---. "Metro Gulutsan (1925-79)." Canadian Slavonic Papers/Revue Canadienne des Slavistes, vol. 21, no. 3, Sept. 1979, pp. 436-37.

---. The Politics of Multiculturalism: A Ukrainian-Canadian Memoir. CIUS P, 2005. 
Macleod, Rod, and Alexander McGuckin. All True Things: A History of the University of Alberta, 1908-2008. U of Alberta P, 2008.

Magocsi, P. R. On Becoming a Ukrainianist. Chair of Ukrainian Studies, University of Toronto, 2018.

---. Preface. Canada's Ukrainians: Negotiating an Identity, edited by Lubomyr Luciuk and Stella Hryniuk, U of Toronto P, 1991, pp. xi-xv.

Malycky, Alexander. Introduction. Canadian Ethnic Studies, vol. 1, no. 1, June 1969, pp. 1-11.

Martynowych, Orest T. "A Ukrainian Canadian in London: Vladimir J. (Kaye) Kysilewsky and the Ukrainian Bureau, 1931-40." Canadian Ethnic Studies, vol. 47, no. 4, 2015, pp. 263-88.

Marunchak, Mykhailo. The Ukrainian Canadians: A History. Ukrainian Academy of Arts and Sciences (UVAN) in Canada, 1982.

Melnyk, Olenka, and Halyna Klid, editors. Canadian Institute of Ukrainian Studies. Celebrating 20 Years. CIUS Newsletter: Commemorative Issue, Oct. 1996.

Mycak, Sonia. "A Different Story by Helen Potrebenko: The Prairie Pioneer Myth ReVisited." Canadian Ethnic Studies, vol. 28, no. 1, 1996, pp. 67-88.

Nebesio, Bohdan Y. Kanads'kyi instytut ukrains'kykh studii, 25 years. CIUS, 2001.

Palmer, Brian D. Canada's 1960s. The Ironies of Identity in a Rebellious Era. U of Toronto P, 2009.

Patrick, James, and Mark J. Kasoff. Canadian Studies in the New Millennium. 2nd ed., U of Toronto P, 2013.

Pered Bramoiu: Narys istorii Instytutu Sv. Volodymyra v Toronti. St. Vladimir Institute, 1969.

Pinczuk, J. R. "Manitoba-Centre of Ukrainian Studies. Department of Slavic Studies in Winnipeg, Canada, 1949-1974." Ukrainian Review, vol. 21, no. 4, 1974, pp. 8595.

Potichnyj, Peter J. My Journey. Ancaster, 2012.

---, editor. Ukraine in the Seventies: Papers and Proceedings of the McMaster Conference on the Contemporary Ukraine, Hamilton, Ont., 1974. Mosaic Press, 1975.

Pritsak, Omeljan. "The Present State of Ukrainian Studies." Canadian Slavonic Papers/Revue canadienne des Slavistes, vol. 14, no. 2, Summer 1972, pp. 139-52.

---. "Ukrainian Studies at Harvard University." Ukrains'kyi istoryk, vol. 24, no. 4, 1969, pp. 63-71.

---. Chomu katedry ukrainoznavstva v Harvardi? Vybir statei na temy nashoi kul'turnoi polityky (1967-1973). Fond Katedr Ukrainoznavstva, 1973.

Prymak, Thomas M. Gathering a Heritage. Ukrainian, Slavonic, and Ethnic Canada and the USA. U of Toronto P, 2015.

Rabchenuk, Paul Thomas. Book review of The Politics of Multiculturalism: A Ukrainian-Canadian Memoir, by Manoly R. Lupul. Harvard Ukrainian Studies, vol. 29, no. 1/4, 2007, pp. 529-31.

Report of the Royal Commission on Bilingualism and Biculturalism. Vol. 4, The Cultural Contribution of the Other Ethnic Groups, Supply and Services Canada, 1976.

Rojas, Carlos Antonio Aguirre. "1968 as a Turning Point in Historical Thinking: Changes in Western Historiography." História, no. 1/2, 2004, pp. 197-218. 
Rozumnyj, Jaroslav. "UVAN in Canada: Fifty Years of Service." Yesterday, Today, Tomorrow: The Ukrainian Community in Canada, edited by Jaroslav Rozumnyj, Ukrainian Academy of Arts and Sciences in Canada, 2004, pp. 117-54.

Rudling, Per A. "Multiculturalism, Memory, and Ritualization: Ukrainian Nationalist Monuments in Edmonton, Alberta." Nationalities Papers, vol. 39, no. 5, 2011, pp. 733-68.

Rudnyts'kyi, Iaroslav B. "Do istorii ukrains'koi menshosty v Kanadi, 1967-1987." Ukrains'kyi istoryk, no. 1-4 (93-96), 1987, pp. 119-24.

Satzewich, Vic. The Ukrainian Diaspora. Routledge, 2002.

Savaryn, Petro (Peter Savaryn). "Kanads'ka fundatsiia ukrains'kykh studii (notatky do istorii)." Zakhidn'okanads'kyi zbirnyk, vol. 5, Kanads'ke Naukove Tovarystvo imeni T. Shevchenka, 2008, pp. 47-149.

---. "Klub ukrains'kykh profesionalistiv." Zakhidn'okanads'kyi zbirnyk, vol. 2, Kanads'ke Naukove Tovarystvo imeni T. Shevchenka, 1975, pp. 286-311.

---. 'Spohady uchasnyka: Polityka, bahatokul'turnist', Kanads'kyi instytut ukrainoznavstva, abetkova Entsyklopediia Ukrainy-2." Zakhidn'okanads'kyi zbirnyk, vol. 3, Kanads'ke Naukove Tovarystvo imeni T. Shevchenka, 1998, pp. 317-83.

---. Z soboiu vzialy Ukrainu. Vid Ternopilla do Al'berty. KVPTs, 2007.

Szafowal, Mykola, and Roman Yaremko, compilers. Universitas Libera Ucrainensis: 1921-2006. Ukrainische Freie Universität, 2006.

Shtohryn, Dmytro M. Svitla i tini Ukrains'kykh studii u Harvardi. Mykola Mikhnovs'kyi Ukrainian Students' Society, 1973.

Slaboshpyts'kyi, Mykola, and Mykola Soroka. Metsenat, iakyi ne vidmovyvsia buty ukraintsem: Petro Iatsyk u spohadakh suchasnykiv: statti, vidhuky ta interv"iu vydatnoho blahodiinyka i hromads'koho diiacha. Iaroslaviv Val, 2002.

Slavutych, Iar. U vyri bahatokul'turnosty. Spohady uchasnyka. Slavuta, 1988.

Sorokolittia Instytutu Sv. Ivana v Edmontoni, 1959. Alberta Printing, 1959.

Steele, James, and Robin Mathews. "Canadianization Revisited: A Comment on Cormier's 'The Canadianization Movement in Context."' Canadian Journal of Sociology/Cahiers canadiens de sociologie, vol. 31, no. 4, 2006, pp. 491-508.

Stevenson, Garth. Building Nations from Diversity: Canadian and American Experience Compared. McGill-Queen's UP, 2014.

Stoddard, Alison Froese. "The Birth of Canada's Multicultural Policy: Plotting the Official Acceptance of Diversity." Dalhousie Faculty of Arts and Social Sciences Halifax Overseas Club Award Essay Competition, 2012. https://cdn.dal.ca/content/dam/dalhousie/pdf/fass/Overseas_2012_FroeseSt oddard.pdf. Accessed 24 Mar. 2019.

Sukhovers'kyi, Mykola (Celestin [Mykola] Suchowersky). Moi spohady. Smoloskyp, 1997.

Ukrainians in Alberta. Ukrainian Pioneers Association of Alberta, 1975.

Ukrains'kyi instytut im. P. Mohyly v mynulomu i maibutn'omu. Trident Press, 1966.

Woycenko, Ol'ha. The Annals of Ukrainian Life in Canada. Vol. 8, Striving for a New Canada: Official Bilingualism and Multiculturalism 1970-1979. CIUS P, 1992.

Wynnyckyj, Oksana A. "St. Sofia School: A Ukrainian Community and Heritage Language School." Polyphony: Bulletin of the Multicultural History Society of Ontario: Heritage Languages in Ontario, vol. 11, no. 1-2, 1989, pp. 137-43. 
"Z zhyttia ukraintsiv v sviti." Suchasnist', vol. 4, 1976, pp. 120-23.

Zimmerman, David. “'Narrow-Minded People': Canadian Universities and the Academic Refugee Crises, 1933-1941." Canadian Historical Review, vol. 88, no. 2, June 2007, pp. 291-315. 